\title{
"Macroeconomic announcements and stock returns in US portfolios formed on operating profitability and investment"
}

\begin{tabular}{|c|c|}
\hline AUTHORS & $\begin{array}{l}\text { Constantinos Alexiou (D https://orcid.org/0000-0002-9481-3066 } \\
\text { Sofoklis Vogiazas (D https://orcid.org/0000-0001-6141-3173 } \\
\text { Abid Taqvi }\end{array}$ \\
\hline ARTICLE INFO & $\begin{array}{l}\text { Constantinos Alexiou, Sofoklis Vogiazas and Abid Taqvi (2018). Macroeconomic } \\
\text { announcements and stock returns in US portfolios formed on operating } \\
\text { profitability and investment. Investment Management and Financial Innovations, } \\
\text { 15(1),68-89. doi:10.21511/imfi.15(1).2018.08 }\end{array}$ \\
\hline DOI & http://dx.doi.org/10.21511/imfi.15(1).2018.08 \\
\hline RELEASED ON & Thursday, 25 January 2018 \\
\hline RECEIVED ON & Thursday, 09 November 2017 \\
\hline ACCEPTED ON & Tuesday, 09 January 2018 \\
\hline LICENSE & $\begin{array}{l}(\mathrm{ccc}) \mathrm{EY} \text {-No } \\
\text { This work is licensed under a Creative Commons Attribution-NonCommercial } 4.0 \\
\text { International License }\end{array}$ \\
\hline JOURNAL & "Investment Management and Financial Innovations" \\
\hline ISSN PRINT & $1810-4967$ \\
\hline ISSN ONLINE & $1812-9358$ \\
\hline PUBLISHER & LLC "Consulting Publishing Company "Business Perspectives" \\
\hline FOUNDER & LLC "Consulting Publishing Company "Business Perspectives" \\
\hline
\end{tabular}

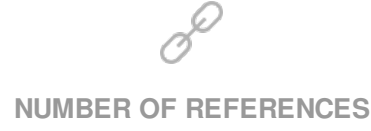

59
NUMBER OF FIGURES

0

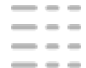

NUMBER OF TABLES

4

(C) The author(s) 2022. This publication is an open access article. 


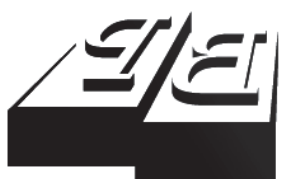

BUSINESS PERSPECTIVES

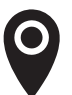

LLC “CPC "Business Perspectives" Hryhorii Skovoroda lane, 10, Sumy, 40022, Ukraine

www.businessperspectives.org

Received on: $9^{\text {th }}$ of November, 2017 Accepted on: $9^{\text {th }}$ of January, 2018

(c) Constantinos Alexiou, Sofoklis Vogiazas, Abid Taqvi, 2018

Constantinos Alexiou, Dr., Associate Professor, Cranfield University, UK.

Sofoklis Vogiazas, Dr., Principal Analyst, Black Sea Trade and Development Bank, Greece.

Abid Taqvi, Research Student, Cranfield University, UK.

\section{ANNOUNCEMENTS AND STOCK RETURNS IN US PORTFOLIOS FORMED ON OPERATING PROFITABILITY AND INVESTMENT}

\begin{abstract}
The authors explore the reaction of US stock portfolio returns to macroeconomic announcements spanning the period from April 1998 to May 2017. Using daily returns of 25 portfolios formed on operating profitability and investment, the authors investigate the extent to which potential asymmetries permeate the stock portfolios following macroeconomic announcements. The three methodological approaches utilized in this study suggest that the ISM non-manufacturing index, employees on non-farm payrolls, retail sales, personal consumption expenditure and initial jobless claims have a significant impact on portfolio returns. Also, portfolios consisting of companies with higher operating profitability and investment level are found to be less responsive to announcements. As the particular area has received little currency over the years, this contribution is of great significance, because it provides insights into the reaction of returns in value-weighted portfolios to announcements on certain macro-indicators. At the same time, the study informs portfolio managers of the implications of macroeconomic news, which drive economic expectations and can reverberate through the expected returns in US stock portfolios.
\end{abstract}

Keywords

macroeconomic announcements, business cycle, Kenneth French value-weighted portfolios, operating profitability, investment, US stock portfolios

JEL Classification E44, G12, G14

\section{INTRODUCTION}

It has been widely argued that macroeconomic announcements influence the behavior of financial assets, while feedback effects from the markets to the economy have also been documented in the literature. A significant body of evidence has established that macroeconomic news generally affects stock returns (see, for instance, McConnell \& Muscarella, 1985; Blose \& Shieh, 1997; Vogt, 1997). Developments in the economic landscape have implications for investors in so far, as they directly affect stock prices especially when these deviate from market expectations (Medovikov, 2016). Studies in this area primarily focus on the effects of macroeconomic announcements on stock indices. It was not until recently that studies have started exploring their effects on portfolio returns. We have opted to use portfolios constructed on the basis of operating profitability and investment, an area that remains relatively novel and under-researched. The choice of this type of portfolios is driven by the investors' preferences given the prominent role of profitability and investment as means of sustainable growth for US companies. In this context, sustainable growth is perceived as a proxy leading indicator of a company's health. 
In our endeavor to explore the reaction of returns to macroeconomic announcements, we use 25 crosssorted portfolios and several key macroeconomic indicators over the period April 1998 to May 2017 for the US market. Our analysis provides a framework that links companies' specific characteristics with the macroeconomic ones. In particular, we purport to identify the nature of macroeconomic announcements that significantly affect stock returns on release data in the chosen portfolios. At the same time, we uncover the response of portfolios formed by companies that exhibit lower profitability or investment versus higher profitability or investment levels. In this direction, by establishing the key macroeconomic variables that portfolio managers should monitor, it will enable them to make informed decisions that contribute meaningfully to the portfolio allocation process.

The rest of the paper is organized as follows. Section 1 provides a concise overview of the literature, while section 2 presents the data followed by the description of the methodological framework utilized in section 3. Section 4 discusses the empirical findings whilst last section provides some concluding remarks.

\section{LITERATURE REVIEW}

The implementation of the capital asset pricing model (CAPM) presented by Sharpe (1964) prompted the development of the arbitrage pricing theory (APT) by Ross (1976), which explains the expected return on a portfolio with respect to a set of factors capturing systematic risk. By using this model to explore the relationship between US stock market returns and various macroeconomic variables, Chen et al. (1986) find that industrial production, changes in risk premium and twists in the yield curve were significant in explaining stock returns.

Given that a large strand of literature focuses on size, book-to-market and momentum factors, we have opted to focus on the equally relevant operating profitability and investment factors. Our approach is justified by Titman et al. (2004) who claim that investment expenditure can be viewed favorably for several reasons, causing increases in stock returns. For instance, a higher investment level may signal a company's confidence in the economy, as well as the market's confidence in the company itself. In addition, several authors conclude that investment announcements generally pose a significant and positive effect on stock returns (see McConnell \& Muscarella, 1985; Blose \& Shieh, 1997; Vogt, 1997). Certainly, there are downfalls associated with these theories. For instance, higher investment expenditure during periods of 'high' stock prices may not reflect the market views (Titman et al., 2004). At the same time, there could be cases where increased investment may have a negative effect on stock returns.
Undoubtedly, there is a link, as well as feedback effects between profitability and investment. Typically, low profits adversely affect business activity which in turn depresses investment leading to weakening output growth (Chan-Lee \& Sutch, 1985). Among the studies linking profitability and stock returns, Haugen and Baker (1996) find that profitable firms tend to present faster growth potential. Yet, this relationship lasts until competitive market entry reduces profits towards equilibrium. Fama and French (2008) established a positive trend between profitability and average returns, whilst in a more recent study, Fama and French (2015) suggest that higher expected earnings are associated with higher expected returns.

Turning to the nexus between investment and stock returns, Richardson and Sloan (2003), Fairfield et al. (2003) found a negative relationship between average returns and investment. Nonetheless, Abarbanell and Bushee (1998), Frankel and Lee (1998), Dechow et al. (2000), Lee et al. (2009) provided evidence suggesting that higher expected cash flows simply future stock returns.

In so far as macroeconomic variables impact increases the returns, Fama (1981) concluded that real stock returns are positively related to investment, real rate of return on capital, money supply, GNP and industrial production. In the same spirit, Geske and Roll (1983) show that industrial production has a positive relationship with stock returns. Moreover, by analyzing the daily reaction of stocks to the unexpected component of announcements on the money stock, the CPI, the unemployment rate, industrial production, and the 
Fed's discount rate, Pearce and Roley (1985) found that surprises have a significantly negative effect on stock prices.

Bernanke and Kuttner (2005) analyze how portfolio returns react to unanticipated changes in the Fed's target rate, while Rahman (2009) finds a causal link between asset return volatility and real economic activity. The study of Flannery and Protopapadakis (2002) indicates that both CPI and PPI affect the level of returns, while Birz and Lott's (2011) results suggest that unemployment and GDP growth significantly affect stock returns. Interestingly, Nikkinen and Sahlström (2004) find that European investors regard US macroeconomic news as important in stock valuation. Building upon the world CAPM model ${ }^{1}$ and using 38 country ETFs, $\mathrm{Du}$ (2017) finds that the world market risk factor is significantly positive for US macroeconomic announcement days with the US monetary policy announcements being the most important drivers.

Amongst the studies that employ multifactor models and announcements, Gosnell and Nejadmalayeri (2010) attest that portfolio returns are significantly affected by inflation, non-farm payrolls, personal income, and consumption. Cenesizoglu (2008) suggests that the stock market reacts asymmetrically to the unanticipated news. In a later study, Cenesizoglu (2011) found that the employees on non-farm payrolls is the most significant factor in explaining returns, whilst portfolios react differently to employment news, especially during expansions. In a comprehensive study that investigates how the issuance of new economic data influences asset prices in the stock, bond and foreign exchange markets, Bartolini et al. (2008) conclude that only a few announcements - the non-farm payroll numbers, the GDP advance release and a private sector manufacturing report - have significant and persistent effects, while most of other data releases examined by the authors generate only transitory or erratic responses. In a more recent study, Medovikov (2016) finds that the impact of economic news on equity returns is non-linear and asymmetric, while the market reacts strongly and negatively to the most unfavorable macroeconomic news. In the same wavelength, Bergbrant and Kelly (2016) provide evidence that market excess returns do respond to changes in macroeconomic forecasts.

\section{DATASET AND TRANSFORMATIONS}

The dataset which is sourced from Kenneth French's database ${ }^{2}$ comprises daily returns for 25 value-weighted portfolios formed on operating profitability and investment. The companies' stocks in these portfolios are traded on the NYSE, AMEX and NASDAQ. The total sample includes 120,000 observations, as it focuses on the period from April 30, 1998 to May 31, 2017. Table 1 in Appendix presents the macroeconomic variables used, the data sources along with the summary statistics.

The business cycle or economic growth is proxied by three different measures: Gross Domestic Product (GDP), the Institute for Supply Management's index (ISM) for the non-manufacturing sector and industrial production. Future GDP growth should affect equity returns (Vassalou, 2003), while an increasing ISM index or industrial production should positively correlate with the stock market. Overall, the factors considered that reflect real economic activity can alter expectations on the future path of the economy. In general, more positive than expected news, so-called surprises, could lead to rising stock prices.

Labor market conditions are proxied by the unemployment rate, the employees on non-farm payrolls and initial jobless claims. In general, stock prices respond to news on the labor market (Andersen \& Bollerslev, 1998; Gosnell \& Nejadmalayeri, 2010; Boyd et al., 2005) and rising unemployment could cause stock prices to fall.

In line with several studies that have accounted for the effect of inflation on returns (Moerman \& van Dijk, 2010; Gosnell \& Nejadmalayeri, 2010; Rangel,

1 In the world CAPM, world market risk is considered the single source of systematic risk underlying asset returns and investors earn a positive premium for exposure to this source of risk (see Solnik, 1974; Grauer et al., 1976).

2 Data on portfolios formed on operating profitability and investment are retrieved from http://mba.tuck.dartmouth.edu/pages/faculty/ken. french/data_library.html 
2011), we use the Consumer Price Index (CPI) and Producer Price Index (PPI). Higher than expected inflation causes companies' cash flows to dwindle, which could lower stock prices (Pearce \& Roley, 1985). Rising consumer demand as captured by retail sales and personal consumption expenditure, in the long run, can ignite increased investment, which in turn can influence stock prices.

US federal agencies regularly report a wide range of macroeconomic variables, through pre-scheduled announcements ${ }^{3}$. As the goal is to measure the effect of the surprise associated with selected macroeconomic factors on the announcement dates, market expectations are required to complement the actual announcements.

Following Balduzzi et al. (2001), we use standardized news variables, which are expressed as follows:

$$
S_{k, t}=\frac{A_{k, t}-E_{k, t}}{\hat{\sigma}_{k}}, \hat{\sigma}_{k}=\sqrt{\operatorname{var}\left(A_{k, t}-E_{k, t}\right)}
$$

where $A_{k, t}$ is the real announced value for the macroeconomic factor $k$ on trading day $t, E_{k, t}$ is the market expectation value on the same day in accordance with analysts' surveys. The difference between $A_{k, t}-E_{k, t}$ is the unexpected (surprise) component of the macroeconomic factor. $\hat{\sigma}_{k}$ is the sample standard deviation of the unexpected component of the news. The use of standardized variables allows comparisons between different macroeconomic variables with differing units. As $\hat{\sigma}_{k}$ is constant for each macroeconomic factor and coefficients are estimated by regressing the returns on the standardized surprise, the standardisation does not affect the statistical significance or the fit of the regression (Hussain, 2011).

As shown in Table 1, the mean for most standardized variables is close to zero thereby confirming unbiasedness in Money Market Services International (MMS) forecasts. We also use a $t$-test to test whether the means of the standardized announcements are significantly different from zero at the 5\% significance level. As only two of the macroeconomic announcements were found to have means different from zero, we conclude that the macroeconomic forecasts are unbiased (Flannery \& Protopapadakis, 2002).

In general, the mean and standard deviation of returns are higher on announcement days than on non-announcements days ${ }^{4}$. Especially, on days with a larger number of announcements, the average returns tend to be much higher, while the volatility is lower. In the announcement days, the higher investment portfolios tend to present lower average returns. The same applies to non-announcement days, although the trend is somewhat less obvious. Furthermore, higher profitability portfolios tend to present lower average returns on announcement days, while the opposite holds for non-announcement days. Although the trend is less visible in investment portfolios, it appears that higher investment portfolios present higher volatility in both the announcement and non-announcement days. In contrast, higher operating profitability portfolios present lower volatility in both the announcement and non-announcement days.

\section{METHODOLOGICAL APPROACH}

In our analysis of the stock returns reaction to the macroeconomic news over the sampling period, we initially estimate an OLS regression with Newey-West (1987) standard errors to account for heteroscedasticity and autocorrelation issues. This setting is similar to Basistha and Kurov (2008). Also, we include a dummy component in line with Cenesizoglu (2011). The model specification is as follows:

$R_{i, t}=\beta_{0, i k}+\sum \beta_{1, i k} S_{k, t}+\sum \beta_{2, i k} I_{k, t}+\varepsilon_{i, t}$,

where $R_{i, t}$ is the return on portfolio $i(i=1,2, \ldots, 25)$ for the 25 cross-sorted portfolios on announcement day $t . S_{k, t}$ is the standardized news variables as shown in equation (1), which is

3 All variables used in our study contain scheduled announcements only. This is because unscheduled announcements may contain a different type of surprise (Basistha \& Kurov, 2008). It should be mentioned that the number of observations is not equal to the number of announcements within the time frame considered due to some announcements without survey expectations. Such announcements have been excluded from our sample.

4 The summary statistics of the portfolios used is not presented in this paper for space considerations. These results are available upon request. 
equal to zero on non-announcement days for each macroeconomic variable. $I_{k, t}$ is a dummy variable that is equal to one if it is an announcement day or zero otherwise ${ }^{5}$. This specification allows for several announcements on the same day which was evident in our data. Therefore, it captures the effect of a particular macroeconomic variable by controlling for other news announcements on the same day. In addition to this, the dummy variable $I_{k, t}$ controls for additional effects on returns during announcement days that is not captured by surprise variables (Cenesizoglu, 2011).

In addition to the OLS estimation, we have employed the MM weighted least squares procedure $^{6}$ as implemented by Yohai (1987) in line with Basistha and Kurov (2008). Also, following Simpson and Ramchander (2008), and Cenesizoglu (2011), we have adopted the Seemingly Unrelated Regression (SUR) methodology which allows for the correlation of error terms across the portfolios.

The adoption of three estimation methodologies serves as a robustness check given the presence of outliers in the data. Potential endogeneity issues can cause significant bias within the empirical estimation, which is common in related studies. Nonetheless, the results of the Durbin-WuHausman test suggest that the null hypothesis that each variable is exogenous cannot be rejected at 5\% level. Furthermore, the Variance Inflation Factor (VIF) test indicates that multicollinearity is not a concern.

\section{ESTIMATION RESULTS}

The results of the three different estimation methodologies used are presented in Appendix (Tables 2, 3 and 4).

Based on the results obtained using the OLS estimation shown in Table 2, it follows that announcements on the macroeconomic variables ISM nonmanufacturing index, employees on non-farm payrolls, retail sales, personal consumption expen- diture and initial jobless claims have a significant effect in explaining the reaction of returns of the portfolios used. More specifically, the employees on non-farm payrolls appear to be the most important variable in explaining returns, as it retains its significance across all portfolios. The trade balance was found to be less significant in the sense that in 11 out of the 25 portfolios it causes a positive reaction to returns.

An increase in the ISM non-manufacturing index was found to have a positive impact on stock returns with the reaction decreasing with higher profitability portfolios. No substantial trend was found in relation to the investment portfolios. An increase in employees on non-farm payrolls was found to have a negative effect on returns. Yet, no trend was found for either the operating profitability or investment portfolios.

Retail sales had a positive effect on returns showing no real trend across both categories of portfolios. Personal consumption expenditure also had a positive reaction to returns showing a negative trend across both portfolios. Therefore, larger reactions were caused by companies in the lower profitability and investment portfolios. Lastly, initial jobless claims had a negative effect on returns. A positive trend can be identified when looking at median values for operating profit portfolios. Therefore, a larger negative reaction was observed from the smallest profitability portfolios. As for the investment portfolios, no real trend was found in relation to the magnitude of the reaction.

The explanatory power of our estimations ranges from $0.8 \%$ to $1.2 \%$ across all portfolios. This shows a low explanatory power, but is in line with previous studies (see Cenesizoglu, 2008).

The results of the SUR regressions as displayed in Table 3 suggest that all coefficients are close to those estimated by OLS, although the significance of few variables has changed across portfolios. For instance, the significance of the ISM non-manufacturing index changed for seven out of the 25

If the announcement day dummy variable, $I_{k, t}$ is identical for multiple variables, we drop the variable in order to avoid multicollinearity. This, however, is not the case in our data.

6 The OLS estimation is sensitive to outliers, while the MM estimation maintains its robustness in the presence of outliers. A prerequisite for the efficiency of MM estimation is the normal distribution of errors. The results of the diagnostic checks suggest that the error terms are normally distributed. 
portfolios. Moreover, trade balance, employees on non-farm payrolls and retail sales have changed for 9,8 and 14 portfolios, respectively. Personal consumption expenditure and initial jobless claims have changes in 14 and 8 portfolios, respectively. More specifically, both variables have an increase in statistical significant causing nine portfolios to become significant for personal consumption expenditure and two for initial jobless claims.

Notably, employees on non-farm payrolls, although presents a drop in significance, it still maintains its significance across all portfolios under the SUR estimation. The trade balance also becomes statistically insignificant in the majority of portfolios, while personal consumption expenditure becomes significant for fifteen portfolios suggesting its importance in explaining the reaction of returns.

According to the MM estimation in Table 4, the personal consumption expenditure becomes insignificant across portfolios. Although the employees on non-farm payroll drops insignificance across several portfolios, the majority of portfolios remain consistent, thus confirming the importance of this variable. In general, both proxies for labor conditions (employees on the non-farm payroll, initial jobless claims) retain their significance in explaining portfolios' returns.

Overall, our results regarding the significance of GDP surprises are akin to the related literature (Cenesizoglu, 2011; Flannery \& Protopapadakis, 2002; Harju \& Hussain, 2011; Bergbrant \& Kelly, 2016). Also in line with all studies, except for Flannery and Protopapadakis (2002), we find a positive effect of GDP's higher than expected announcements.

Unlike Nikkinen et al. (2006), we find that announcements on the ISM non-manufacturing index are statistically significant in line with Harju and Hussain (2009). The variation in our results can be attributed to different markets, time periods and the methodology used, i.e., Nikkinen et al. (2006) used all G7 countries combined.

As for the positive, yet the insignificant effect of the news on industrial production, our results are in line with Pearce and Roley (1985), Cenesizoglu
(2011), Flannery and Protopapadakis (2002). Fama (1981), Geske and Roll (1983) report a positive and significant relationship of industrial production with returns, which can be attributed to different time periods considered.

The negative effect of inflation is in line with several studies (Pearce \& Roley, 1985; Andersen \& Bollerslev, 1998; Flannery \& Protopapadakis, 2002; Andersen et al., 2007; Harju \& Hussain, 2009; Gosnell \& Nejadmalayeri, 2010) as bouts of inflation reduce market confidence (Gregoriou et al., 2009). Nonetheless, most of the aforementioned studies report a significant effect of inflation on returns, while in our estimations, both proxies for inflation were found to be insignificant, which is in line with Harju and Hussain (2009). This divergence could be attributed to different time periods, data frequency, or the estimation methods employed in these studies. Another plausible explanation relates to the potential interaction of other variables considered in our study with inflation in the sense that the impact of inflation is already captured by variables with a higher frequency of announcements.

As for the effect of employees on non-farm payrolls, our results are consistent with a number of studies, namely Andersenet et al. (2007), Gosnell and Nejadmalayeri (2010), and Cenesizoglu (2011). The same applies to the trade balance surprises, where their positive effect on returns is in line with Andersen et al. (2007) and Cenesizoglu (2011).

In line with Flannery and Protopapadakis (2002), Harju and Hussain (2009) Gosnell and Nejadmalayeri (2010), and Cenesizoglu (2011), we find a positive effect of housing starts on returns. However, Gosnell and Nejadmalayeri (2010), and Cenesizoglu (2011) found a significant role for housing starts, while Flannery and Protopapadakis (2002), Harju and Hussain (2009) found an insignificant one, consistent with our findings.

Personal consumption expenditure was found to be statistically significant, in line with Gregoriou et al. (2009) who also find a primary role for consumption in explaining excess returns, while Cenesizoglu (2011) and Flannery and Protopapadakis (2002) report an insignifi- 
cant effect. Similarly, the insignificant effect of leading indicators in our estimations is in line with Cenesizoglu (2011) and Flannery and Protopapadakis (2002).

The unemployment rate results were also consistent with Flannery and Protopapadakis (2002) and Pearce and Roley (1985). Similar to Flannery and Protopapadakis (2002), and Nikkinen et al. (2006), we also report an insignificant effect of construction spending and consumer confidence, respectively. As our results indicate, a positive surprise in initial jobless claims causes a significant decrease in portfolios' returns, which is in line with Nguyen and Ngo (2014) study of the Asian stock markets.

Our findings suggest that retail sales produce a positive and significant reaction on returns, which is akin to Harju and Hussain (2009). However, Flannery and Protopapadakis (2002), and Cenesizoglu (2011) found retail sales to be statistically insignificant. The different results could be attributed to the fact that our portfolios may well contain a larger number of cyclical stocks relative to other studies.

It is worth noting that the majority of studies referred to in this paper do not focus on announcement effects on portfolio returns. Although several authors investigate announcement surprises, their portfolios were formed on either size and book-to-market value or momentum returns (Gosnell \& Nejadmalayeri, 2010; Cenesizoglu, 2011; Bergbrant \& Kelly, 2016). The notable variation in our results might be ascribed to the nature of our portfolios, i.e., they are formed on operating profitability and investment.

In view of the preceding analysis, four key channels of new information on the relationship between portfolio returns and macroeconomic announcements emerge:

a. Positive surprises in the announcements for the ISM non-manufacturing index, which signal stronger than expected expectations about the economy do reflect on stock prices possibly through the corporate performance channel, i.e., earnings, cash flows, the required rate of return. Thus, our results indicate that an ISM non-manufacturing index surprise is positively associated with rising returns for all portfolios.

b. Employees on non-farm payrolls are negatively associated with returns. Although it may seem counterintuitive that an improvement in labor market conditions would reduce the daily stock returns for the operating profit and investment portfolios, the result remains consistent with past studies irrespective of the estimation methodology employed 7 . In line with Boydet et al. (2005), during expansionary periods, a positive surprise in the employment rate can cause expectations for rising interest rates which trigger a negative reaction of stock prices. Although it also leads to a rise in growth expectations, which instead should cause a positive effect on stock prices, according to Boyd et al. (2005), the interest rate effect dominates the growth rate during expansionary phases. In addition, based on NBER recession dates, around $86.1 \%$ of the daily observations of returns in our study were taken during expansionary phases. At the same time, the initial jobless claims outline a weakening economy as reflected in decreasing returns.

c. Retail sales are found to have a positive impact on returns, in line with our expectations. Retail sales reflect spending trends; higher retail sales suggest an increasing demand for consumer goods. Increasing demand can boost companies' future earnings, hence causing stock prices to rise. Personal consumption expenditure was also found to have a positive impact on returns.

d. The trend analysis performed in the portfolios used in the study ${ }^{8}$ did not indicate any real trends in employees on non-farm payrolls and retail sales. Therefore, it seems that all crosssorted portfolios are equally volatile to these announcements. The practical implication is that, regardless of how a portfolio is constructed, a portfolio manager should hedge against volatility from unanticipated announcements

$7 \quad$ See McQueen and Roley (1993), Boyd et al. (2005), Andersen et al. (2007) and Cenesizoglu (2011).

8 The results of the trend analysis are available upon request. 
on employees on non-farm payroll and retail sales. On the other hand, the ISM non-manufacturing index, personal consumption expenditure, and initial jobless claims contained trends suggesting that the aggregate stocks return within the different portfolios reacted in different ways to surprises on announcements.

In general, higher profitability portfolios were found to react differently relative to lower profitability ones. In practical terms, portfolio managers wishing to minimize the short-term volatility in returns stemming from announcements should prefer portfolios comprising of companies with higher operating profitability levels.

Personal consumption expenditure was one of the few variables that exhibited a trend across investment portfolios. It appears that companies with lower investment levels tend to have a larger return reaction. Thus, a portfolio manager can par- tially hedge the risk arising from announcements on personal consumption by constructing portfolios with high investment companies. While there are studies which suggest that lower investment levels are associated with higher returns, these mostly focus on the magnitude of future returns and not the volatility of returns?

On the whole, our results suggest that by constructing portfolios based on companies with higher operating profitability and investment levels, there is potential to minimize the volatility risk against announcements regarding the ISM non-manufacturing index, personal consumption expenditure, and initial jobless claims. However, employees on non-farm payrolls and retail sales have a uniform reaction across all portfolios with no meaningful trend, hence, with a potential to minimize volatility for these two announcements in operating profitability and investment portfolios.

\section{CONCLUSION}

This study explores the reaction of returns to macroeconomic announcements across 25 portfolios formed on operating profitability and investment which constitutes a novel aspect. To the best of our knowledge, such study has not been done before. The practical implication of our results for investors in the US market relates to the significant influence that certain variables such as the ISM non-manufacturing index, employees on non-farm payrolls, retail sales, personal consumption expenditure and initial jobless claims exert to portfolio returns. Furthermore, the ISM non-manufacturing index, personal consumption expenditure, and initial jobless claims are found to shape certain trends across different portfolios. Therefore, by constructing portfolios with companies that present higher operating profitability and investment levels, an investor can potentially reduce the volatility risk arising from announcements on the ISM non-manufacturing index, personal consumption expenditure, and initial jobless claims.

An implicit assumption in our research is that the US market is weakly efficient. If this is not the case, then the expected part of an announcement will also have an impact on stock returns. Hence, testing both the expected and unexpected component of an announcement may have provided us with a greater insight into whether the US market is weakly efficient and therefore more conclusive results on return reactions.

Although our results suggest that macroeconomic announcements affect value-weighted portfolios formed on profitability and investment, they explain a relatively small part of the total variability. Yet, the latter is evident in the related literature (see, for instance, Bergbrant \& Kelly, 2016). In addition, our analysis considers only the target surprise, leaving the path surprise as a future research avenue, although, as highlighted by Gilbert et al. (2015), the price response to a particular type of announcement cannot be analyzed in isolation.

9 See studies from Fairfield et al. (2003), Titman et al. (2004) Fama and French (2008), Fama and French (2015). 


\section{REFERENCES}

1. Abarbanell, J. S., Bushee, B. J. (1998). Abnormal Returns to a Fundamental Analysis Strategy. The Accounting Review, 73, 19-45. Retrieved from http://www.jstor. org/stable/248340

2. Andersen, T. G., Bollerslev, T. (1998). DM-dollar intraday volatility: activity pattern, macroeconomic announcements, and longer run dependencies. Journal of Finance, 53, 219-265. https://doi.org/10.1111/00221082.85732

3. Andersen, T. G., Bollerslev, T., Diebold, F. X., \& Vega, C. (2007). Real-time price discovery in global stock, bond and foreign exchange markets. Journal of International Economics, 73(2), 251-277. https://doi.org/10.1016/j. jinteco.2007.02.004

4. Balduzzi, P., Elton, E. J., \& Green, T. C. (2001). Economic news and bond prices: Evidence from the U.S. Treasury market. Journal of Financial and Quantitative Analysis, 36, 523-543. https://doi. org/10.2307/2676223

5. Bartolini, L., Goldberg, L. S., \& Sacarny, A. (2008). How Economic News Moves Markets. Federal Reserve Bank of New York Current Issues in Economics and Finance, 14(6). Retrieved from https://www.newyorkfed.org/research/current_issues/ci14-6.html

6. Basistha, A., \& Kurov, A. (2008). Macroeconomic cycles and the stock market's reaction to monetary policy. Journal of Banking \& Finance, 32(12), 26062616. https://doi.org/10.1016/j. jbankfin.2008.05.012

7. Bernanke, B. S., \& Kuttner, K. N (2005). What explains the stock market's reaction to federal reserve policy? Journal of Finance, 60, 1221-1257. https://doi.org/10.1111/ j.1540-6261.2005.00760.x

8. Bergbrant, M. C., \& Kelly, P. J. (2016). Macroeconomic Expectations and the Size, Value, and Momentum Factors. Financial Management, 45, 809-844. https:// doi.org/10.1111/fima.12140
9. Birz, G., \& Lott Jr, J. R. (2011). The effect of macroeconomic news on stock returns: New evidence from newspaper coverage. Journal of Banking \& Finance, 35, 2791-2800. https://doi.org/10.1016/j.jbankfin.2011.03.006

10. Blose, L. E., \& Shieh, J. C. P. (1997). Tobin's $q$-Ratio and Market Reaction to Capital Investment Announcements. Financial Review, 32, 449-476. https://doi. org/10.1111/j.1540-6288.1997. tb00434.x

11. Boyd, J. H., Hu, J., \& Jagannathan, R. (2005). The stock market's reaction to unemployment news: why bad news is usually good for stocks. The Journal of Finance, 60, 649-672. https://doi.org/10.1111/ j.1540-6261.2005.00742.x

12. Brennan, M. J., Jegadeesh, N., \& Swaminathan, B. (1993). Investment analysis and the adjustment of stock-prices to common information. Review of Financial Studies, 6(4), 799-824. https://doi.org/10.1093/rfs/6.4.799

13. Carhart, M. M. (1997). On Persistence in Mutual Fund Performance. Journal of Finance, 52(1), 57-82. https://doi. org/10.1111/j.1540-6261.1997. tb03808.x

14. Cenesizoglu, T. (2011). Size, book-to-market ratio and macroeconomic news. Journal of Empirical Finance, 18(2), 248270. http://dx.doi.org/10.2139/ ssrn.940034

15. Cenesizoglu, T. (2008). Asymmetries in the Reaction of Stock Prices to Macroeconomic News. HEC Montreal (Working paper).

16. Chan-Lee, I. H., \& Sutch, H. (1985). Profits and Rates of Return. OECD Economic Studies, 5. http://dx.doi. org/10.1787/468348310348

17. Chen, N. F., Roll, R., \& Ross, S. A. (1986). Economic Forces and the Stock Market. Journal of Business, 59, 383-403. https://doi. org/10.1086/29634

18. Cohen, R. B., Gompers, P. A., \& Vuolteenaho, T. (2002). Who underreacts to cashflownews? evidence from trading between individuals and institutions. Journal of Financial Economics, 66(2-3), 409-462. https://doi.org/10.1016/ S0304-405X(02)00229-5

19. Dechow, P. M., Hutton, A. P., \& Sloan, R. G. (2000). The Relation between Analysts' Forecasts of Long-Term Earnings Growth and Stock Price Performance Following Equity Offerings. Contemporary Accounting Research, 17(1), 1-32. https://doi. org/10.1111/j.1911-3846.2000. tb00908.x

20. Du, D. (2017). US

macroannouncements and international asset pricing. International Journal of Finance and Economics, 22, 352-367. https://doi.org/10.1002/ijfe.1592

21. Fairfield, P. M., Whisenant, S., \& Yohn, T. L. (2003) Accrued Earnings and Growth: Implications for Future Profitability and Market Mispricing. The Accounting Review, 78(1), 353-371. https://doi. org/10.2308/accr.2003.78.1.353

22. Fama, E. F. (1981). Stock returns, real activity, inflation and money. American Economic Review, 71(4), 545-565. Retrieved from http:// www.jstor.org/stable/1806180

23. Fama, E. F., \& French, K. R. (2006). Profitability, investment and average returns. Journal of Financial Economics, 82, 491-518.

24. Fama, E. F., \& French, K. R. (2008). Dissecting Anomalies. The Journal of Finance, 63, 1653-1678. https://doi.org/10.1111/j.15406261.2008.01371.x

25. Fama, E. F., \& French, K. R. (2015). A five-factor asset pricing model. Journal of Financial Economics, 116, 1-22. http://dx.doi. org/10.1016/j.jfineco.2014.10.010

26. Flannery, M. J., \& Protopapadakis, A. A. (2002). Macroeconomic factors do influence aggregate stock returns. Review of Financial Studies, 15, 751-782. https://doi. org/10.1093/rfs/15.3.751 
27. Frankel, R., \& Lee, C. (1998). Accounting valuation, market expectation, and cross sectional stock returns. Journal of Accounting and Economics, 25(3), 283-319. https://doi.org/10.1016/ S0165-4101(98)00026-3

28. Geske, R., \& Roll, R. (1983). The fiscal and monetary linkage between stock returns and inflation. Journal of Finance, 38(1), 1-33. https://doi. org/10.1111/j.1540-6261.1983. tb03623.x

29. Gilbert, T., Scotti, C., Strasser, G., \& Vega, C. (2015). Is the Intrinsic Value of Macroeconomic News Announcements Related to their Asset Price Impact? (Finance and Economics Discussion Series 2015-046). Washington: Board of Governors of the Federal Reserve System. http://dx.doi. org/10.17016/FEDS.2015.046

30. Gosnell, T., \& Nejadmalayeri, A. (2010). Macroeconomic news and risk factor innovations. Managerial Finance, 36, 566-582. https://doi. org/10.1108/03074351011050316

31. Grauer, F. L. A., Litzenberger, R. H., \& Stehle, R. E. (1976) Sharing rules and equilibrium in an international capital market under uncertainty. Journal of Financial Economics, 3, 233-256. https://doi.org/10.1016/0304405X(76)90005-2

32. Gregoriou, A, Hunter, J., \& Wu, F. (2009). An empirical investigation of the relationship between the real economy and stock returns for the United States. Journal of Policy Modelling, 31(1), 133-143. https://doi.org/10.1016/j.jpolmod.2008.04.010

33. Gürkaynak, R. S., Sack, B., \& Swanson, E. (2005). The sensitivity of long-term interest rates to economic news: Evidence and implications for macroeconomic models. American Economic Review, 95(1), 425-436. https://doi. org/10.1257/0002828053828446

34. Harju, K., \& Hussain, S. M. (2009). Intraday Seasonalities and Macroeconomic News Announcements. European Financial Management, 17, 367-
390. https://doi.org/10.1111/ j.1468-036X.2009.00512.x

35. Haugen, R. A., \& Baker, N. L. (1996). Commonalityin the determinants of expected stock returns. Journal of Financial Economics, 41(3), 401-439. https://doi.org/10.1016/0304405X(95)00868-F

36. Hussain, S. M. (2011). Simultaneous monetary policy announcements and international stock markets response: An intraday analysis. Journal of Banking \& Finance, 35(3), 752-764. https://doi.org/10.1016/j.jbankfin.2010.09.002

37. Kurov, A. (2010). Investor sentiment and the stock market's reaction to monetary policy. Journal of Banking \& Finance, 34(1), 139-149. https:// doi.org/10.1016/j.jbankfin.2009.07.010

38. Lee, C., Ng, D., \& Swaminathan, B. (2009). Testing International Asset Pricing Models Using Implied Costs of Capital. Journal of Financial and Quantitative Analysis, 44(2), 307-335. https://doi.org/10.1017/ S0022109009090164

39. Li, L., \& Hu, Z. F. (1998). Responses of stock markets to macroeconomic announcements across economic states (IMF Working Paper, No. 79).

40. McConnell, J., \& Muscarella, C. (1985). Corporate capital expenditure decisions and the market value of the firm. Journal of Financial Economics, 14, 399422. https://doi.org/10.1016/0304405X(85)90006-6

41. McQueen, G., \& Roley, V. V. (1993). Stock prices, news, and business conditions. Review of Financial Studies, 6(3), 683-707. https://doi.org/10.1093/rfs/5.3.683

42. Medovikov, I. (2016). When does the stock market listen to economic news? New evidence from copulas and news wires. Journal of Banking \& Finance, 65, 27-40. https://doi.org/10.1016/j. jbankfin.2016.01.004

43. Moerman, G. A., \& Van Dijk, M. A. (2010). Inflation Risk and
International Asset Returns. Journal of Banking \& Finance, 34, 840-855. https://doi.org/10.1016/j. jbankfin.2009.09.014

44. Newey, W. K., \& West, K. D. (1987). A Simple, Positive Semi-Definite Heteroskedasticity and Autocorrelation Consistent Covariance Matrix. Econometrica, 55(3), 703-708. Retrieved from http://www.jstor.org/stable/1913610

45. Nguyen, T., \& Ngo, C. (2014) Impacts of the US macroeconomic news on Asian stock markets. Journal of Risk Finance, 15(2), 149-179. https://doi.org/10.1108/ JRF-09-2013-0064

46. Nikkinen, J., Omran, M., Sahlström, P., \& Äijö, J. (2006). Global stock market reactions to scheduled US macroeconomic news announcements. Global Finance Journal, 17(1), 92 104. https://doi.org/10.1016/j. gf. 2006.06.003

47. Nikkinen, J., \& Sahlström, P. (2004). Scheduled domestic and US macroeconomic news and stock valuation in Europe. Journal of Multinational Financial Management, 14(3), 201-215. https://doi.org/10.1016/j.mulfin.2003.01.001

48. Pearce, D. K., \& Roley, V. V. (1985) Stock prices and economic news. Journal of Business, 58, 49-67. http://dx.doi.org/10.1086/296282

49. Rahman, A. (2009). Industrylevel stock returns volatility and aggregate economic activity in Australia. Applied Financial Economics, 19, 509-525. http://dx.doi. org/10.1080/09603100802359968

50. Rangel, J. G. (2011). Macroeconomic news, announcements, and stock market jump intensity dynamics. Journal of Banking \& Finance, 35(5), 1263 1276. https://doi.org/10.1016/j. jbankfin.2010.10.009

51. Richardson, S. A., \& Sloan, R. G. (2003). External Financing and Future Stock Returns (Working Paper No. 03-03). Rodney L. White Center for Financial Research. 
52. Ross, S. A. (1976). The Arbitrage Theory of Capital Asset Pricing. Journal of Economic Theory, 13(3), 341-360. https://doi. org/10.1016/0022-0531(76)90046-6

53. Sharpe, W. F. (1964). Capital Asset Prices: A Theory of Market Equilibrium under Conditions of Risk. Journal of Finance, 19(3), 425-442. https://doi. org/10.1111/j.1540-6261.1964. tb02865.x

54. Solnik, B. H. (1974). An equilibrium model of the international capital market. Journal of Economic Theory, 8, 500-524. http://dx.doi. org/10.1016/0022-0531(74)90024-6
55. Simpson, M. W., \& Ramchander, S. (2008). An inquiry into the economic fundamentals of the Fama and French equity factors. Journal of Empirical Finance, 15(5), 801-815. https:// doi.org/10.1016/j.jempfin.2008.02.003

56. Titman, S., Wei, K., \& Xie, F. (2004). Capital investments and stock returns. Journal of Financial and Quantitative Analysis, 39, 677-700. https://doi.org/10.1017/ S0022109000003173

57. Vassalou, M. (2003). News related to future GDP growth as a risk factor in equity returns. Journal of Financial Economics, 68(1), 47-73. https://doi.org/10.1016/ S0304-405X(02)00248-9

58. Vogt, S. C. (1997). Cash flow and capital spending: evidence from capital expenditure announcement. Financial Management, 26, 44-57. https:// doi.org/10.2307/3666166

59. Yohai, V. J. (1987). High breakdown-point and high efficiency robust estimates for regression. The Annals of Statistics, 15, 642-656. Retrieved from http://www.jstor.org/ stable/2241331

\section{APPENDIX}

Table 1. Macroeconomic variables and summary statistics for announcements

\begin{tabular}{|c|c|c|c|c|c|c|c|c|}
\hline Announcements & Observations & Source & Start date & End date & $\begin{array}{c}\text { Announcement } \\
\text { time }\end{array}$ & Mean & Min & $\operatorname{Max}$ \\
\hline \multicolumn{9}{|c|}{ Quarterly announcements } \\
\hline Real GDP & 51 & BEA & $01 / 30 / 2003$ & $04 / 28 / 2017$ & 8:30 A.M. & 0.0632 & -2.3027 & 2.3027 \\
\hline \multicolumn{9}{|c|}{ Monthly announcements } \\
\hline $\begin{array}{l}\text { ISM } \\
\text { non-manufacturing }\end{array}$ & 111 & NAPM & 02/05/2008 & 05/03/2017 & 10:00 A.M. & 0.0572 & -4.1430 & 2.1502 \\
\hline $\begin{array}{l}\text { Industrial } \\
\text { production }\end{array}$ & 203 & FRB & 06/16/1998 & 05/16/2017 & 9:15 A.M. & -0.1245 & -5.4940 & 3.0217 \\
\hline $\begin{array}{l}\text { Leading indicator } \\
\text { index }\end{array}$ & 161 & $\mathrm{CB}$ & 06/02/1998 & 05/18/2017 & 8:30 A.M. & 0.1686 & -2.8277 & 2.8277 \\
\hline Trade balance & 223 & BEA & 06/18/1998 & $05 / 04 / 2017$ & 8:30 A.M. & -0.0050 & -3.0755 & 3.3609 \\
\hline Housing starts & 222 & $\mathrm{BC}$ & 06/16/1998 & $05 / 16 / 2017$ & 8:30 A.M. & 0.0460 & -3.1560 & 3.1934 \\
\hline $\begin{array}{l}\text { Construction } \\
\text { spending }\end{array}$ & 159 & $\mathrm{BC}$ & 08/01/2003 & 05/01/2017 & 10:00 A.M. & -0.1327 & -3.0309 & 3.1475 \\
\hline $\begin{array}{l}\text { Consumer } \\
\text { confidence }\end{array}$ & 227 & $\mathrm{CB}$ & 06/30/1998 & 05/30/2017 & 10:00 A.M. & 0.0263 & -2.8043 & 2.4637 \\
\hline $\begin{array}{l}\text { Unemployment } \\
\text { rate }\end{array}$ & 162 & BLS & 07/02/1998 & 05/05/2017 & 8:30 A.M. & -0.2775 & -3.4585 & 2.7668 \\
\hline $\begin{array}{l}\text { Employee on non- } \\
\text { farm payrolls }\end{array}$ & 127 & BLS & 08/30/2006 & $05 / 03 / 2017$ & 8:30 A.M. & -0.0786 & -3.6496 & 3.6682 \\
\hline $\mathrm{CPI}$ & 147 & BLS & $06 / 16 / 1998$ & $04 / 17 / 2017$ & 8:30 A.M. & -0.0855 & -3.1411 & 3.1411 \\
\hline PPI & 168 & BLS & 07/10/1998 & $12 / 13 / 2013$ & 8:30 A.M. & 0.0607 & -2.6027 & 3.6871 \\
\hline Retail sales & 168 & $\mathrm{BC}$ & 06/13/2001 & $05 / 12 / 2017$ & 8:30 A.M. & -0.0081 & -2.7154 & 7.8067 \\
\hline $\begin{array}{l}\text { Personal } \\
\text { consumption } \\
\text { expenditure }\end{array}$ & 60 & BEA & 06/30/2005 & 05/30/2017 & 8:30/10:00 A.M. & -0.4737 & -1.5789 & 1.5789 \\
\hline \multicolumn{9}{|c|}{ Weekly announcements } \\
\hline $\begin{array}{l}\text { Initial jobless } \\
\text { claims }\end{array}$ & 724 & ETA & 08/08/2002 & $05 / 25 / 2017$ & 8:30 A.M. & 0.0575 & -4.9324 & 4.6202 \\
\hline
\end{tabular}


Table 2. The reaction of portfolios to macroeconomic announcements (OLS Newey West standard errors)

\begin{tabular}{|c|c|c|c|c|c|}
\hline \multirow{2}{*}{ Announcements } & \multicolumn{5}{|c|}{ Small OP } \\
\hline & $1 \mathrm{st}(\mathrm{I})$ & 2nd(I) & $3 r d(I)$ & 4th(I) & 5 th(I) \\
\hline \multicolumn{6}{|l|}{ Quarterly announcements } \\
\hline \multirow{2}{*}{ Real GDP } & 0.137 & 0.266 & -0.041 & 0.189 & 0.104 \\
\hline & $(0.208)$ & $(0.198)$ & $(0.269)$ & $(0.186)$ & $(0.249)$ \\
\hline \multicolumn{6}{|l|}{ Monthly announcements } \\
\hline \multirow{2}{*}{ ISM non-manufacturing } & $0.366^{* *}$ & $0.354^{* *}$ & $0.324^{* *}$ & $0.399 * * *$ & $0.432^{* * *}$ \\
\hline & $(0.164)$ & $(0.141)$ & $(0.137)$ & $(0.147)$ & $(0.148)$ \\
\hline \multirow{2}{*}{ Industrial production } & -0.004 & -0.026 & 0.065 & 0.101 & -0.016 \\
\hline & $(0.152)$ & $(0.124)$ & $(0.206)$ & $(0.136)$ & $(0.169)$ \\
\hline \multirow{2}{*}{ Leading indicator index } & 0.011 & 0.133 & 0.046 & -0.049 & 0.002 \\
\hline & $(0.129)$ & $(0.120)$ & $(0.119)$ & $(0.151)$ & $(0.129)$ \\
\hline \multirow{2}{*}{ Trade balance } & $0.228^{*}$ & 0.194 & 0.121 & $0.247^{*}$ & $0.226^{*}$ \\
\hline & $(0.135)$ & $(0.127)$ & $(0.120)$ & $(0.135)$ & $(0.125)$ \\
\hline \multirow{2}{*}{ Housing starts } & -0.076 & -0.017 & 0.016 & 0.00315 & -0.126 \\
\hline & $(0.129)$ & $(0.099)$ & $(0.124)$ & $(0.122)$ & $(0.118)$ \\
\hline \multirow{2}{*}{ Construction spending } & 0.154 & 0.151 & 0.077 & 0.153 & 0.089 \\
\hline & $(0.187)$ & $(0.152)$ & $(0.171)$ & $(0.180)$ & $(0.153)$ \\
\hline \multirow{2}{*}{ Consumer confidence } & 0.077 & 0.006 & 0.015 & -0.051 & 0.034 \\
\hline & $(0.147)$ & $(0.125)$ & $(0.156)$ & $(0.179)$ & $(0.153)$ \\
\hline \multirow{2}{*}{ Unemployment rate } & -0.089 & -0.025 & 0.014 & -0.039 & -0.046 \\
\hline & $(0.102)$ & $(0.096)$ & $(0.094)$ & $(0.099)$ & $(0.104)$ \\
\hline \multirow{2}{*}{ Employee on non-farm payrolls } & $-0.367^{* *}$ & $-0.321^{* *}$ & $-0.342^{* *}$ & $-0.372^{* *}$ & $-0.313^{* *}$ \\
\hline & $(0.176)$ & $(0.141)$ & $(0.145)$ & $(0.161)$ & $(0.130)$ \\
\hline \multirow{2}{*}{$\mathrm{CPI}$} & -0.158 & -0.018 & 0.027 & -0.036 & -0.104 \\
\hline & $(0.180)$ & $(0.147)$ & $(0.164)$ & $(0.186)$ & $(0.152)$ \\
\hline \multirow{2}{*}{ PPI } & -0.090 & -0.102 & -0.053 & -0.081 & -0.097 \\
\hline & $(0.106)$ & $(0.094)$ & $(0.104)$ & $(0.114)$ & $(0.108)$ \\
\hline \multirow{2}{*}{ Retail sales } & $0.277^{*}$ & $0.261^{*}$ & $0.291^{* *}$ & $0.346^{* *}$ & $0.340^{* * *}$ \\
\hline & $(0.165)$ & $(0.133)$ & $(0.133)$ & $(0.164)$ & $(0.113)$ \\
\hline \multirow{2}{*}{ Personal consumption } & $0.201^{*}$ & $0.180^{*}$ & $0.220^{* *}$ & $0.245^{* *}$ & $0.207^{* *}$ \\
\hline & $(0.118)$ & $(0.097)$ & $(0.098)$ & $(0.109)$ & $(0.104)$ \\
\hline \multicolumn{6}{|l|}{ Weekly announcements } \\
\hline \multirow{2}{*}{ Initial jobless claims } & $-0.165^{* * *}$ & -0.050 & $-0.110^{*}$ & $-0.127^{* *}$ & $-0.109^{*}$ \\
\hline & $(0.064)$ & $(0.054)$ & $(0.058)$ & $(0.061)$ & $(0.056)$ \\
\hline R-squared & 0.009 & 0.009 & 0.007 & 0.009 & 0.008 \\
\hline F Statistic & $1.61^{* *}$ & $1.57^{* *}$ & $1.46^{* *}$ & $1.91^{* * *}$ & $2.02^{* * *}$ \\
\hline Announcements & & & d OP & & \\
\hline Announcements & $1 s t(I)$ & 2nd(I) & $3 r d(I)$ & 4th(I) & 5 th $(\mathrm{I})$ \\
\hline Quarterly announcements & & & & & \\
\hline Real GDP & 0.268 & 0.272 & $0.287 *$ & 0.108 & 0.246 \\
\hline Real GDP & $(0.185)$ & $(0.208)$ & $(0.149)$ & $(0.190)$ & $(0.213)$ \\
\hline Monthly announcements & & & & & \\
\hline ISM non-manufacturino & $0.380 * * *$ & $0.302^{* *}$ & $0.338^{* * *}$ & $0.379^{* * *}$ & $0.245^{* *}$ \\
\hline ISM non-manutacturing & $(0.133)$ & $(0.131)$ & $(0.115)$ & $(0.137)$ & $(0.117)$ \\
\hline Inductrial nroduction & -0.054 & 0.013 & 0.020 & -0.025 & -0.112 \\
\hline Industrial production & $(0.103)$ & $(0.129)$ & $(0.114)$ & $(0.125)$ & $(0.139)$ \\
\hline I oadina indicator indor & 0.045 & 0.053 & 0.087 & -0.0142 & 0.033 \\
\hline Leading indicator Index & $(0.118)$ & $(0.119)$ & $(0.115)$ & $(0.112)$ & $(0.119)$ \\
\hline & 0.117 & 0.079 & $0.220^{*}$ & $0.178^{*}$ & 0.168 \\
\hline Irade balance & $(0.104)$ & $(0.101)$ & $(0.113)$ & $(0.096)$ & $(0.104)$ \\
\hline & 0.055 & 0.043 & 0.008 & 0.00641 & -0.050 \\
\hline Housing starts & $(0.091)$ & $(0.103)$ & $(0.099)$ & $(0.103)$ & $(0.106)$ \\
\hline
\end{tabular}


Table 2 (cont). The reaction of portfolios to macroeconomic announcements (OLS Newey West standard errors)

\begin{tabular}{|c|c|c|c|c|c|}
\hline \multirow{2}{*}{ Announcements } & \multicolumn{5}{|c|}{ 2nd OP } \\
\hline & $1 s t(I)$ & 2nd(I) & $3 r d(I)$ & 4th(I) & 5 th $(I)$ \\
\hline \multirow{2}{*}{ Construction spending } & 0.072 & 0.134 & 0.108 & 0.097 & 0.049 \\
\hline & $(0.155)$ & $(0.151)$ & $(0.148)$ & $(0.141)$ & $(0.137)$ \\
\hline \multirow{2}{*}{ Consumer confidence } & -0.032 & 0.007 & 0.068 & -0.091 & 0.029 \\
\hline & $(0.152)$ & $(0.140)$ & $(0.119)$ & $(0.152)$ & $(0.162)$ \\
\hline \multirow{2}{*}{ Unemployment rate } & -0.048 & 0.062 & -0.024 & 0.017 & -0.004 \\
\hline & $(0.083)$ & $(0.085)$ & $(0.082)$ & $(0.084)$ & $(0.093)$ \\
\hline \multirow{2}{*}{ Employee on non-farm payrolls } & $-0.379^{* * *}$ & $-0.359^{* *}$ & $-0.367^{* *}$ & $-0.333^{* * *}$ & $-0.352 * * *$ \\
\hline & $(0.129)$ & $(0.148)$ & $(0.154)$ & $(0.127)$ & $(0.101)$ \\
\hline \multirow{2}{*}{$\mathrm{CPI}$} & -0.078 & -0.085 & -0.064 & -0.178 & -0.110 \\
\hline & $(0.120)$ & $(0.127)$ & $(0.141)$ & $(0.143)$ & $(0.134)$ \\
\hline \multirow{2}{*}{ PPI } & -0.026 & 0.029 & 0.019 & -0.029 & -0.072 \\
\hline & $(0.088)$ & $(0.092)$ & $(0.096)$ & $(0.094)$ & $(0.088)$ \\
\hline \multirow{2}{*}{ Retail sales } & $0.228^{*}$ & $0.238^{*}$ & $0.222^{*}$ & $0.250^{* *}$ & $0.250^{*}$ \\
\hline & $(0.123)$ & $(0.144)$ & $(0.122)$ & $(0.123)$ & $(0.129)$ \\
\hline \multirow{2}{*}{ Personal consumption } & $0.213^{* *}$ & $0.215^{* *}$ & 0.119 & 0.140 & $0.163^{*}$ \\
\hline & $(0.094)$ & $(0.085)$ & $(0.100)$ & $(0.090)$ & $(0.094)$ \\
\hline \multicolumn{6}{|l|}{ Weekly announcements } \\
\hline \multirow{2}{*}{ Initial jobless claims } & $-0.103^{* *}$ & -0.072 & $-0.136^{* * *}$ & $-0.097^{* *}$ & $-0.123^{* * *}$ \\
\hline & $(0.051)$ & $(0.047)$ & $(0.049)$ & $(0.049)$ & $(0.045)$ \\
\hline R-squared & 0.010 & 0.009 & 0.010 & 0.011 & 0.008 \\
\hline F Statistic & $1.94^{* * *}$ & $1.52^{* *}$ & $2.03^{* * *}$ & $2.27^{* * *}$ & $1.87^{* * *}$ \\
\hline \multirow{2}{*}{ Announcements } & \multicolumn{5}{|c|}{ 3rdOP } \\
\hline & 1 st(I) & $2 n d(I)$ & $3 r d(I)$ & 4th(I) & $5 \operatorname{th}(\mathrm{I})$ \\
\hline \multicolumn{6}{|l|}{ Quarterly announcements } \\
\hline \multirow{2}{*}{ Real GDP } & 0.185 & 0.227 & 0.216 & 0.178 & 0.180 \\
\hline & $(0.159)$ & $(0.145)$ & $(0.169)$ & $(0.182)$ & $(0.184)$ \\
\hline \multicolumn{6}{|l|}{ Monthly announcements } \\
\hline \multirow{2}{*}{ ISM non-manufacturing } & $0.295^{* *}$ & 0.208 & $0.274^{* *}$ & $0.291^{* *}$ & $0.317^{* *}$ \\
\hline & $(0.124)$ & $(0.144)$ & $(0.121)$ & $(0.143)$ & $(0.128)$ \\
\hline \multirow{2}{*}{ Indus trial production } & 0.064 & -0.078 & -0.070 & 0.033 & -0.056 \\
\hline & $(0.137)$ & $(0.119)$ & $(0.109)$ & $(0.142)$ & $(0.148)$ \\
\hline & 0.0259 & 0.091 & 0.021 & 0.090 & -0.068 \\
\hline Leading indicator index & $(0.115)$ & $(0.099)$ & $(0.100)$ & $(0.108)$ & $(0.121)$ \\
\hline & 0.128 & 0.135 & 0.108 & 0.208 & $0.242^{* *}$ \\
\hline Trade balance & $(0.109)$ & $(0.093)$ & $(0.107)$ & $(0.129)$ & $(0.114)$ \\
\hline & 0.041 & 0.072 & 0.063 & 0.062 & -0.010 \\
\hline Housing starts & $(0.099)$ & $(0.093)$ & $(0.089)$ & $(0.095)$ & $(0.107)$ \\
\hline & 0.169 & 0.072 & 0.119 & 0.163 & 0.153 \\
\hline Construction spending & $(0.166)$ & $(0.129)$ & $(0.132)$ & $(0.159)$ & $(0.153)$ \\
\hline & 0.034 & -0.084 & -0.059 & -0.069 & -0.037 \\
\hline Consumer confidence & $(0.141)$ & $(0.150)$ & $(0.150)$ & $(0.142)$ & $(0.147)$ \\
\hline & -0.011 & 0.045 & 0.040 & -0.017 & -0.041 \\
\hline Unemployment rate & $(0.086)$ & $(0.091)$ & $(0.082)$ & $(0.102)$ & $(0.091)$ \\
\hline & $-0.335^{* *}$ & $-0.341^{* * *}$ & $-0.291^{* *}$ & $-0.334^{* * *}$ & $-0.354^{* * *}$ \\
\hline Employee non-farm payrolls & $(0.138)$ & $(0.120)$ & $(0.117)$ & $(0.125)$ & $(0.114)$ \\
\hline & -0.072 & -0.103 & -0.127 & -0.094 & -0.149 \\
\hline CPI & $(0.130)$ & $(0.110)$ & $(0.121)$ & $(0.147)$ & $(0.146)$ \\
\hline PPI & -0.099 & -0.096 & -0.099 & -0.013 & -0.024 \\
\hline PPI & $(0.090)$ & $(0.098)$ & $(0.099)$ & $(0.103)$ & $(0.103)$ \\
\hline & $0.366^{* * *}$ & $0.233^{* *}$ & $0.315^{* * *}$ & $0.225^{*}$ & 0.184 \\
\hline Retail sales & $(0.108)$ & $(0.103)$ & $(0.109)$ & $(0.124)$ & $(0.144)$ \\
\hline & $0.165^{*}$ & $0.165^{* *}$ & $0.171^{* *}$ & 0.106 & 0.136 \\
\hline Personal consumption & $(0.099)$ & $(0.074)$ & $(0.082)$ & $(0.093)$ & $(0.089)$ \\
\hline
\end{tabular}


Table 2 (cont). The reaction of portfolios to macroeconomic announcements (OLS Newey West standard errors)

\begin{tabular}{|c|c|c|c|c|c|}
\hline \multirow{2}{*}{ Announcements } & \multicolumn{5}{|c|}{$3 r d O P$} \\
\hline & 1st(I) & 2nd(I) & $\operatorname{3rd}(\mathrm{I})$ & 4th(I) & 5th(I) \\
\hline \multicolumn{6}{|c|}{ Weekly announcements } \\
\hline \multirow{2}{*}{ Initial jobless claims } & -0.070 & $-0.109^{* *}$ & $-0.127^{* *}$ & $-0.096^{* *}$ & $-0.112^{* *}$ \\
\hline & $(0.059)$ & $(0.045)$ & $(0.054)$ & $(0.044)$ & $(0.051)$ \\
\hline R-squared & 0.010 & 0.010 & 0.012 & 0.008 & 0.009 \\
\hline F Statistic & $1.96^{* * *}$ & $2.13^{* * *}$ & $1.62^{* *}$ & $1.44^{*}$ & $2.30^{* * *}$ \\
\hline \multirow{2}{*}{ Announcements } & \multicolumn{5}{|c|}{ 4th OP } \\
\hline & $1 \mathrm{st}(\mathrm{I})$ & 2nd(I) & $3 r d(I)$ & 4th(I) & 5th(I) \\
\hline \multicolumn{6}{|l|}{ Quarterly announcements } \\
\hline \multirow[t]{2}{*}{ Real GDP } & 0.121 & 0.218 & 0.243 & $0.254^{*}$ & 0.135 \\
\hline & $(0.148)$ & $(0.152)$ & $(0.150)$ & $(0.144)$ & $(0.174)$ \\
\hline \multicolumn{6}{|l|}{ Monthly announcements } \\
\hline \multirow{2}{*}{ ISM non-manufacturing } & $0.283^{* *}$ & 0.134 & 0.188 & 0.196 & $0.304^{* *}$ \\
\hline & $(0.116)$ & $(0.149)$ & $(0.125)$ & $(0.134)$ & $(0.134)$ \\
\hline \multirow{2}{*}{ Industrial production } & -0.010 & -0.049 & -0.074 & -0.029 & -0.045 \\
\hline & $(0.107)$ & $(0.094)$ & $(0.152)$ & $(0.137)$ & $(0.138)$ \\
\hline \multirow{2}{*}{ Leading indicator index } & 0.097 & 0.114 & 0.014 & 0.033 & 0.084 \\
\hline & $(0.106)$ & $(0.100)$ & $(0.093)$ & $(0.106)$ & $(0.109)$ \\
\hline \multirow{2}{*}{ Trade balance } & $0.148^{*}$ & $0.143^{*}$ & 0.089 & 0.171 & $0.219^{*}$ \\
\hline & $(0.081)$ & $(0.081)$ & $(0.080)$ & $(0.124)$ & $(0.119)$ \\
\hline \multirow{2}{*}{ Housing starts } & 0.100 & 0.051 & 0.059 & 0.052 & 0.000 \\
\hline & $(0.081)$ & $(0.082)$ & $(0.088)$ & $(0.095)$ & $(0.092)$ \\
\hline \multirow{2}{*}{ Construction spending } & 0.095 & 0.090 & 0.080 & 0.166 & 0.114 \\
\hline & $(0.138)$ & $(0.113)$ & $(0.123)$ & $(0.151)$ & $(0.129)$ \\
\hline \multirow{2}{*}{ Consumer confidence } & -0.056 & 0.000 & -0.068 & -0.057 & 0.084 \\
\hline & $(0.138)$ & $(0.138)$ & $(0.126)$ & $(0.144)$ & $(0.147)$ \\
\hline \multirow{2}{*}{ Unemployment rate } & -0.011 & -0.059 & 0.036 & 0.012 & 0.026 \\
\hline & $(0.092)$ & $(0.087)$ & $(0.084)$ & $(0.084)$ & $(0.087)$ \\
\hline \multirow{2}{*}{ Employee non-farm payrolls } & $-0.267^{* *}$ & $-0.260^{* * *}$ & $-0.232^{* *}$ & $-0.342 * * *$ & $-0.265^{* *}$ \\
\hline & $(0.124)$ & $(0.099)$ & $(0.105)$ & $(0.131)$ & $(0.104)$ \\
\hline \multirow{2}{*}{$\mathrm{CPI}$} & -0.032 & -0.100 & -0.148 & -0.096 & -0.138 \\
\hline & $(0.092)$ & $(0.109)$ & $(0.100)$ & $(0.145)$ & $(0.118)$ \\
\hline & -0.012 & -0.027 & -0.051 & -0.102 & -0.068 \\
\hline PPI & $(0.079)$ & $(0.078)$ & $(0.091)$ & $(0.089)$ & $(0.104)$ \\
\hline & $0.282^{* *}$ & 0.139 & $0.242^{* * *}$ & $0.271^{* * *}$ & $0.292^{* *}$ \\
\hline Retaıl sales & $(0.112)$ & $(0.131)$ & $(0.086)$ & $(0.104)$ & $(0.114)$ \\
\hline & $0.209 * *$ & 0.116 & $0.168^{* *}$ & $0.170^{* *}$ & 0.138 \\
\hline Personal consumption & $(0.093)$ & $(0.083)$ & $(0.078)$ & $(0.084)$ & $(0.088)$ \\
\hline Weekly announcements & & & & & \\
\hline & $-0.098^{*}$ & $-0.092 * *$ & $-0.094^{* *}$ & $-0.109 * *$ & $-0.081^{*}$ \\
\hline Initial jobless claims & $(0.052)$ & $(0.039)$ & $(0.039)$ & $(0.044)$ & $(0.046)$ \\
\hline R-squared & 0.010 & 0.007 & 0.009 & 0.010 & 0.008 \\
\hline F Statistic & $1.98^{* * *}$ & $1.49^{* *}$ & $2.12^{* * *}$ & $1.95^{* * *}$ & $1.66^{* *}$ \\
\hline & & & ge OP & & \\
\hline Announcements & 1st(I) & 2nd(I) & $3 r d(I)$ & 4th(I) & 5th(I) \\
\hline & Quarterl & uncements & & & \\
\hline & 0.232 & 0.061 & 0.179 & 0.203 & 0.195 \\
\hline Real GDP & $(0.143)$ & $(0.173)$ & $(0.135)$ & $(0.174)$ & $(0.153)$ \\
\hline Monthly announcements & & & & & \\
\hline & $0.295^{* *}$ & 0.155 & $0.220^{*}$ & $0.239^{*}$ & 0.252 \\
\hline ISM non-manufacturing & $(0.123)$ & $(0.114)$ & $(0.131)$ & $(0.139)$ & $(0.160)$ \\
\hline & -0.093 & -0.079 & 0.014 & -0.086 & -0.076 \\
\hline Industrial production & $(0.139)$ & $(0.126)$ & $(0.119)$ & $(0.157)$ & $(0.136)$ \\
\hline
\end{tabular}


Table 2 (cont). The reaction of portfolios to macroeconomic announcements (OLS Newey West standard errors)

\begin{tabular}{|c|c|c|c|c|c|}
\hline \multirow{2}{*}{ Announcements } & \multicolumn{5}{|c|}{ Large OP } \\
\hline & 1st(I) & 2nd(I) & $3 r d(I)$ & 4th(I) & 5 th $(I)$ \\
\hline \multirow{2}{*}{ Leading indicator index } & 0.074 & 0.085 & -0.016 & 0.125 & 0.055 \\
\hline & $(0.092)$ & $(0.088)$ & $(0.103)$ & $(0.117)$ & $(0.107)$ \\
\hline \multirow{2}{*}{ Trade balance } & $0.152 *$ & 0.100 & $0.168^{*}$ & 0.104 & 0.140 \\
\hline & $(0.083)$ & $(0.076)$ & $(0.101)$ & $(0.081)$ & $(0.098)$ \\
\hline \multirow{2}{*}{ Housing starts } & 0.099 & 0.025 & 0.089 & 0.051 & -0.058 \\
\hline & $(0.085)$ & $(0.090)$ & $(0.082)$ & $(0.083)$ & $(0.107)$ \\
\hline \multirow{2}{*}{ Construction spending } & 0.101 & 0.069 & 0.178 & 0.084 & 0.141 \\
\hline & $(0.121)$ & $(0.104)$ & $(0.137)$ & $(0.129)$ & $(0.144)$ \\
\hline \multirow{2}{*}{ Consumer confidence } & -0.100 & -0.126 & -0.047 & -0.055 & 0.054 \\
\hline & $(0.129)$ & $(0.139)$ & $(0.124)$ & $(0.163)$ & $(0.146)$ \\
\hline \multirow{2}{*}{ Unemployment rate } & -0.0538 & -0.036 & -0.018 & -0.022 & -0.019 \\
\hline & $(0.076)$ & $(0.069)$ & $(0.069)$ & $(0.085)$ & $(0.079)$ \\
\hline \multirow{2}{*}{ Employee non-farm payrolls } & $-0.328^{* *}$ & $-0.204^{*}$ & $-0.272 * *$ & $-0.319 * * *$ & $-0.410^{* * *}$ \\
\hline & $(0.134)$ & $(0.107)$ & $(0.106)$ & $(0.111)$ & $(0.120)$ \\
\hline \multirow{2}{*}{$\mathrm{CPI}$} & -0.077 & -0.097 & -0.078 & -0.104 & -0.089 \\
\hline & $(0.112)$ & $(0.095)$ & $(0.123)$ & $(0.112)$ & $(0.130)$ \\
\hline \multirow{2}{*}{ PPI } & -0.035 & -0.075 & -0.032 & -0.139 & -0.033 \\
\hline & $(0.078)$ & $(0.069)$ & $(0.0810)$ & $(0.095)$ & $(0.100)$ \\
\hline \multirow{2}{*}{ Retail sales } & 0.184 & 0.191 & $0.258^{* * *}$ & $0.216^{* *}$ & $0.253^{* *}$ \\
\hline & $(0.122)$ & $(0.122)$ & $(0.097)$ & $(0.108)$ & $(0.122)$ \\
\hline \multirow{2}{*}{ Personal consumption } & $0.126^{*}$ & 0.101 & 0.114 & 0.115 & 0.073 \\
\hline & $(0.075)$ & $(0.071)$ & $(0.076)$ & $(0.084)$ & $(0.090)$ \\
\hline \multicolumn{6}{|l|}{ Weekly announcements } \\
\hline \multirow{2}{*}{ Initial jobless claims } & $-0.116^{* *}$ & $-0.076^{*}$ & $-0.071^{*}$ & $-0.096^{* *}$ & $-0.109 * *$ \\
\hline & $(0.052)$ & $(0.039)$ & $(0.040)$ & $(0.041)$ & $(0.047)$ \\
\hline R-squared & 0.012 & 0.008 & 0.008 & 0.008 & 0.008 \\
\hline F Statistic & $2.03^{* * *}$ & 1.32 & $1.65^{* *}$ & $1.76^{* * *}$ & $1.79^{* * *}$ \\
\hline
\end{tabular}

Notes: 1 . The table displays the coefficients for all macroeconomic announcements. The standard error is presented in parentheses. $\left.{ }^{*}\right)$ denotes significance at the $10 \%$ level; $\left({ }^{* *}\right)$ denotes significance at the $5 \%$ level; $\left(^{* * *}\right)$ denotes significance at the $1 \%$ level. 2 . ith OP denotes the ith portfolio formed on operating profitability. ith(I) denotes the ith portfolio formed on investment.

Table 3. The reaction of portfolios to macroeconomic announcement (SUR)

\begin{tabular}{|c|c|c|c|c|c|}
\hline \multirow{2}{*}{ Announcements } & \multicolumn{5}{|c|}{ Small OP } \\
\hline & 1st(I) & 2nd(I) & $3 r d(I)$ & 4th(I) & $5 \operatorname{th}(\mathrm{I})$ \\
\hline \multicolumn{6}{|l|}{ Quarterly announcements } \\
\hline \multirow{2}{*}{ Real GDP } & 0.137 & 0.266 & -0.041 & 0.189 & 0.104 \\
\hline & $(0.236)$ & $(0.203)$ & $(0.212)$ & $(0.236)$ & $(0.240)$ \\
\hline \multicolumn{6}{|l|}{ Monthly announcements } \\
\hline \multirow{2}{*}{ ISM non-manufacturing } & $0.366^{* *}$ & $0.354^{* *}$ & $0.324^{* *}$ & $0.399 * *$ & $0.432 * * *$ \\
\hline & $(0.163)$ & $(0.141)$ & $(0.147)$ & $(0.163)$ & $(0.166)$ \\
\hline \multirow{2}{*}{ Industrial production } & -0.004 & -0.026 & 0.065 & 0.101 & -0.016 \\
\hline & $(0.115)$ & $(0.099)$ & $(0.103)$ & $(0.115)$ & $(0.117)$ \\
\hline \multirow{2}{*}{ Leading indicator index } & 0.0112 & 0.133 & 0.046 & -0.049 & 0.002 \\
\hline & $(0.115)$ & $(0.099)$ & $(0.103)$ & $(0.115)$ & $(0.117)$ \\
\hline \multirow{2}{*}{ Trade balance } & $0.228^{* *}$ & $0.194^{*}$ & 0.121 & $0.247^{* *}$ & $0.226^{*}$ \\
\hline & $(0.115)$ & $(0.099)$ & $(0.103)$ & $(0.115)$ & $(0.117)$ \\
\hline \multirow{2}{*}{ Housing starts } & -0.076 & -0.017 & 0.016 & 0.003 & -0.126 \\
\hline & $(0.116)$ & $(0.100)$ & $(0.104)$ & $(0.116)$ & $(0.118)$ \\
\hline \multirow{2}{*}{ Construction spending } & 0.154 & 0.151 & 0.077 & 0.153 & 0.089 \\
\hline & $(0.136)$ & $(0.117)$ & $(0.122)$ & $(0.136)$ & $(0.139)$ \\
\hline \multirow{2}{*}{ Consumer confidence } & 0.077 & 0.006 & 0.015 & -0.051 & 0.034 \\
\hline & $(0.115)$ & $(0.099)$ & $(0.103)$ & $(0.115)$ & $(0.117)$ \\
\hline
\end{tabular}


Table 3 (cont). The reaction of portfolios to macroeconomic announcement (SUR)

\begin{tabular}{|c|c|c|c|c|c|}
\hline \multirow{2}{*}{ Announcements } & \multicolumn{5}{|c|}{ Small OP } \\
\hline & $1 \mathrm{st}(\mathrm{I})$ & $2 n d(I)$ & $3 r d(I)$ & 4th(I) & $5 \operatorname{th}(\mathrm{I})$ \\
\hline \multirow{2}{*}{ Unemployment rate } & -0.089 & -0.025 & 0.014 & -0.039 & -0.046 \\
\hline & $(0.116)$ & $(0.100)$ & $(0.104)$ & $(0.116)$ & $(0.118)$ \\
\hline \multirow{2}{*}{ Employee on non-farm payrolls } & $-0.367^{* *}$ & $-0.321 * *$ & $-0.342^{* *}$ & $-0.372^{* *}$ & $-0.313^{* *}$ \\
\hline & $(0.154)$ & $(0.132)$ & $(0.138)$ & $(0.153)$ & $(0.156)$ \\
\hline \multirow{2}{*}{$\mathrm{CPI}$} & -0.158 & -0.018 & 0.027 & -0.036 & -0.104 \\
\hline & $(0.115)$ & $(0.099)$ & $(0.103)$ & $(0.115)$ & $(0.117)$ \\
\hline \multirow{2}{*}{ PPI } & -0.090 & -0.102 & -0.053 & -0.081 & -0.097 \\
\hline & $(0.128)$ & $(0.110)$ & $(0.115)$ & $(0.128)$ & $(0.130)$ \\
\hline \multirow{2}{*}{ Retail sales } & $0.277^{* *}$ & $0.261^{* *}$ & $0.291^{* * *}$ & $0.346^{* * *}$ & $0.340^{* * *}$ \\
\hline & $(0.126)$ & $(0.108)$ & $(0.113)$ & $(0.126)$ & $(0.128)$ \\
\hline \multirow{2}{*}{ Personal consumption } & 0.201 & 0.180 & $0.220^{*}$ & $0.245^{*}$ & 0.207 \\
\hline & $(0.149)$ & $(0.128)$ & $(0.133)$ & $(0.149)$ & $(0.151)$ \\
\hline \multicolumn{6}{|l|}{ Weekly announcements } \\
\hline \multirow{2}{*}{ Initial jobless claims } & $-0.165^{* * *}$ & -0.050 & $-0.110^{*}$ & $-0.127^{* *}$ & $-0.109^{*}$ \\
\hline & $(0.064)$ & $(0.055)$ & $(0.057)$ & $(0.064)$ & $(0.065)$ \\
\hline R-squared & 0.010 & 0.010 & 0.009 & 0.011 & 0.010 \\
\hline Chi-squared & $47.66^{* *}$ & $49.12^{* *}$ & 41.85 & $52.07^{* *}$ & $47.14^{* *}$ \\
\hline \multirow{2}{*}{ Announcements } & \multicolumn{5}{|c|}{ 2nd OP } \\
\hline & $1 \mathrm{st}(\mathrm{I})$ & $2 n d(I)$ & $3 \mathbf{r d}(\mathrm{I})$ & 4th(I) & $5 \operatorname{th}(\mathrm{I})$ \\
\hline \multicolumn{6}{|l|}{ Quarterly announcements } \\
\hline \multirow{2}{*}{ Real GDP } & 0.268 & 0.272 & 0.287 & 0.108 & 0.246 \\
\hline & $(0.184)$ & $(0.187)$ & $(0.193)$ & $(0.190)$ & $(0.202)$ \\
\hline \multicolumn{6}{|l|}{ Monthly announcements } \\
\hline \multirow{2}{*}{ ISM non-manufacturing } & $0.380^{* * *}$ & $0.302^{* *}$ & $0.338^{* *}$ & $0.379^{* * *}$ & $0.245^{*}$ \\
\hline & $(0.128)$ & $(0.129)$ & $(0.134)$ & $(0.131)$ & $(0.140)$ \\
\hline \multirow{2}{*}{ Industrial production } & -0.054 & 0.013 & 0.020 & -0.025 & -0.112 \\
\hline & $(0.090)$ & $(0.091)$ & $(0.094)$ & $(0.093)$ & $(0.099)$ \\
\hline \multirow{2}{*}{ Leading indicator index } & 0.045 & 0.053 & 0.087 & -0.014 & 0.033 \\
\hline & $(0.090)$ & $(0.091)$ & $(0.094)$ & $(0.092)$ & $(0.098)$ \\
\hline \multirow{2}{*}{ Trade balance } & 0.117 & 0.079 & $0.220^{* *}$ & $0.178^{*}$ & $0.168^{*}$ \\
\hline & $(0.090)$ & $(0.091)$ & $(0.094)$ & $(0.093)$ & $(0.098)$ \\
\hline \multirow{2}{*}{ Housing starts } & 0.055 & 0.043 & 0.008 & 0.006 & -0.050 \\
\hline & $(0.091)$ & $(0.092)$ & $(0.095)$ & $(0.094)$ & $(0.100)$ \\
\hline \multirow{2}{*}{ Construction spending } & 0.072 & 0.134 & 0.108 & 0.097 & 0.049 \\
\hline & $(0.107)$ & $(0.108)$ & $(0.112)$ & $(0.110)$ & $(0.117)$ \\
\hline Consumer confidonco & -0.032 & 0.007 & 0.068 & -0.091 & 0.029 \\
\hline Consumer conilaence & $(0.090)$ & $(0.091)$ & $(0.094)$ & $(0.092)$ & $(0.098)$ \\
\hline Hnemployment rete & -0.048 & 0.062 & -0.024 & 0.017 & -0.004 \\
\hline Unemployment rate & $(0.091)$ & $(0.092)$ & $(0.095)$ & $(0.093)$ & $(0.099)$ \\
\hline & $-0.379 * * *$ & $-0.359 * * *$ & $-0.367^{* * *}$ & $-0.333 * * *$ & $-0.352 * * *$ \\
\hline Employee on non-tarm payrolls & $(0.120)$ & $(0.122)$ & $(0.126)$ & $(0.124)$ & $(0.131)$ \\
\hline$C \mathrm{PI}$ & -0.078 & -0.085 & -0.064 & $-0.178^{*}$ & -0.110 \\
\hline CPT & $(0.090)$ & $(0.091)$ & $(0.094)$ & $(0.093)$ & $(0.099)$ \\
\hline & -0.026 & 0.029 & 0.019 & -0.029 & -0.072 \\
\hline PPI & $(0.100)$ & $(0.101)$ & $(0.104)$ & $(0.103)$ & $(0.109)$ \\
\hline Retail sales & $0.228^{* *}$ & $0.238^{* *}$ & $0.222^{* *}$ & $0.250^{* *}$ & $0.250^{* *}$ \\
\hline Retall sales & $(0.098)$ & $(0.100)$ & $(0.103)$ & $(0.101)$ & $(0.108)$ \\
\hline & $0.213^{*}$ & $0.215^{*}$ & 0.119 & 0.140 & 0.163 \\
\hline Personal consumption & $(0.116)$ & $(0.118)$ & $(0.122)$ & $(0.120)$ & $(0.127)$ \\
\hline
\end{tabular}


Table 3 (cont). The reaction of portfolios to macroeconomic announcement (SUR)

\begin{tabular}{|c|c|c|c|c|c|}
\hline \multirow{2}{*}{ Announcements } & \multicolumn{5}{|c|}{ 2nd OP } \\
\hline & 1 st $(I)$ & 2nd(I) & $3 r d(I)$ & 4th(I) & 5 th $(I)$ \\
\hline \multicolumn{6}{|l|}{ Weekly announcements } \\
\hline Initial jobless claims & $-0.103^{* *}$ & -0.072 & $-0.136^{* * *}$ & $-0.097^{*}$ & $-0.123^{* *}$ \\
\hline \multirow{2}{*}{ R-squared } & $(0.050)$ & $(0.051)$ & $(0.052)$ & $(0.052)$ & $(0.055)$ \\
\hline & 0.010 & 0.010 & 0.010 & 0.012 & 0.009 \\
\hline Chi-squared & $50.90^{* *}$ & $48.98^{* *}$ & $50.01^{* *}$ & $60.42^{* * *}$ & $42.59^{*}$ \\
\hline \multirow{2}{*}{ Announcements } & \multicolumn{5}{|c|}{ 3rd OP } \\
\hline & $1 s t(I)$ & 2nd(I) & $3 \operatorname{rd}(\mathrm{I})$ & 4th(I) & 5 th(I) \\
\hline \multicolumn{6}{|l|}{ Quarterly announcements } \\
\hline \multirow{2}{*}{ Real GDP } & 0.121 & 0.218 & 0.243 & 0.254 & 0.135 \\
\hline & $(0.168)$ & $(0.165)$ & $(0.160)$ & $(0.180)$ & $(0.207)$ \\
\hline \multicolumn{6}{|l|}{ Monthly announcements } \\
\hline \multirow{2}{*}{ ISM non-manufacturing } & $0.295^{* *}$ & $0.208^{*}$ & $0.274^{* *}$ & $0.291^{* *}$ & $0.317^{* *}$ \\
\hline & $(0.133)$ & $(0.121)$ & $(0.116)$ & $(0.132)$ & $(0.141)$ \\
\hline \multirow{2}{*}{ Industrial production } & 0.064 & -0.078 & -0.070 & 0.033 & -0.056 \\
\hline & $(0.094)$ & $(0.086)$ & $(0.082)$ & $(0.093)$ & $(0.100)$ \\
\hline \multirow{2}{*}{ Leading indicator index } & 0.026 & 0.091 & 0.021 & 0.090 & -0.068 \\
\hline & $(0.094)$ & $(0.085)$ & $(0.082)$ & $(0.093)$ & $(0.099)$ \\
\hline \multirow{2}{*}{ Trade balance } & 0.128 & 0.135 & 0.108 & $0.208^{* *}$ & $0.242 * *$ \\
\hline & $(0.094)$ & $(0.086)$ & $(0.082)$ & $(0.093)$ & $(0.100)$ \\
\hline \multirow{2}{*}{ Housing starts } & 0.041 & 0.072 & 0.063 & 0.062 & -0.010 \\
\hline & $(0.095)$ & $(0.087)$ & $(0.083)$ & $(0.094)$ & $(0.101)$ \\
\hline \multirow{2}{*}{ Construction spending } & 0.169 & 0.072 & 0.119 & 0.163 & 0.153 \\
\hline & $(0.111)$ & $(0.101)$ & $(0.097)$ & $(0.111)$ & $(0.118)$ \\
\hline \multirow{2}{*}{ Consumer confidence } & 0.034 & -0.084 & -0.060 & -0.069 & -0.037 \\
\hline & $(0.094)$ & $(0.085)$ & $(0.082)$ & $(0.093)$ & $(0.099)$ \\
\hline \multirow{2}{*}{ Unemployment rate } & -0.011 & 0.045 & 0.040 & -0.017 & -0.041 \\
\hline & $(0.095)$ & $(0.086)$ & $(0.082)$ & $(0.094)$ & $(0.100)$ \\
\hline \multirow{2}{*}{ Employee on non-farm payrolls } & $-0.335^{* * *}$ & $-0.341 * * *$ & $-0.291^{* * *}$ & $-0.334 * * *$ & $-0.354^{* * *}$ \\
\hline & $(0.125)$ & $(0.114)$ & $(0.109)$ & $(0.125)$ & $(0.133)$ \\
\hline \multirow{2}{*}{ CPI } & -0.072 & -0.103 & -0.127 & -0.094 & -0.149 \\
\hline & $(0.094)$ & $(0.086)$ & $(0.082)$ & $(0.093)$ & $(0.099)$ \\
\hline \multirow{2}{*}{ PPI } & -0.099 & -0.096 & -0.099 & -0.013 & -0.024 \\
\hline & $(0.104)$ & $(0.095)$ & $(0.091)$ & $(0.104)$ & $(0.110)$ \\
\hline Retail sales & $0.366^{* * *}$ & $0.233^{* *}$ & $0.315 * * *$ & $0.225^{* *}$ & $0.184^{*}$ \\
\hline Netan saics & $(0.102)$ & $(0.093)$ & $(0.090)$ & $(0.102)$ & $(0.109)$ \\
\hline Personal consumption & 0.165 & 0.165 & 0.171 & 0.106 & 0.136 \\
\hline & $(0.121)$ & $(0.110)$ & $(0.106)$ & $(0.121)$ & $(0.129)$ \\
\hline Weekly announcements & & & & & \\
\hline Initial jobless claims & -0.070 & $-0.109 * *$ & $-0.127 * * *$ & $-0.096^{*}$ & $-0.112^{* *}$ \\
\hline Initral jobless claims & $(0.052)$ & $(0.048)$ & $(0.046)$ & $(0.052)$ & $(0.055)$ \\
\hline R-squared & 0.010 & 0.011 & 0.013 & 0.009 & 0.011 \\
\hline Chi-squared & $50.18^{* *}$ & $51.34^{* *}$ & $63.95^{* * *}$ & $44.22^{*}$ & $53.81^{* * *}$ \\
\hline Announcements & & & 4th OP & & \\
\hline Amouncements & 1st(I) & 2nd(I) & $3 r d(I)$ & 4th(I) & 5 th $(I)$ \\
\hline Quarterly announcements & & & & & \\
\hline Real GDP & 0.232 & 0.061 & 0.179 & 0.203 & 0.195 \\
\hline 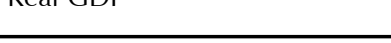 & $(0.168)$ & $(0.151)$ & $(0.162)$ & $(0.182)$ & $(0.203)$ \\
\hline Monthly announcements & & & & & \\
\hline ISM non-manufacturino & $0.283^{* *}$ & 0.134 & $0.188^{*}$ & 0.196 & $0.304^{* *}$ \\
\hline 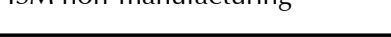 & $(0.116)$ & $(0.114)$ & $(0.111)$ & $(0.125)$ & $(0.144)$ \\
\hline
\end{tabular}


Table 3 (cont). The reaction of portfolios to macroeconomic announcement (SUR)

\begin{tabular}{|c|c|c|c|c|c|}
\hline \multirow{2}{*}{ Announcements } & \multicolumn{5}{|c|}{ 4th OP } \\
\hline & 1st(I) & 2nd(I) & $3 r d(I)$ & 4th(I) & 5 th $(\mathrm{I})$ \\
\hline \multirow{2}{*}{ Industrial production } & -0.010 & -0.049 & -0.074 & -0.029 & -0.045 \\
\hline & $(0.082)$ & $(0.081)$ & $(0.078)$ & $(0.088)$ & $(0.101)$ \\
\hline \multirow{2}{*}{ Leading indicator index } & 0.097 & 0.114 & 0.014 & 0.033 & 0.084 \\
\hline & $(0.082)$ & $(0.080)$ & $(0.08)$ & $(0.088)$ & $(0.101)$ \\
\hline \multirow{2}{*}{ Trade balance } & $0.148^{*}$ & $0.143^{*}$ & 0.089 & $0.171^{*}$ & $0.219^{* *}$ \\
\hline & $(0.082)$ & $(0.081)$ & $(0.08)$ & $(0.088)$ & $(0.101)$ \\
\hline \multirow{2}{*}{ Housing starts } & 0.100 & 0.0512 & 0.059 & 0.052 & 0.000 \\
\hline & $(0.083)$ & $(0.082)$ & $(0.079)$ & $(0.089)$ & $(0.102)$ \\
\hline \multirow{2}{*}{ Construction spending } & 0.095 & 0.090 & 0.080 & 0.166 & 0.114 \\
\hline & $(0.097)$ & $(0.096)$ & $(0.093)$ & $(0.104)$ & $(0.120)$ \\
\hline \multirow{2}{*}{ Consumer confidence } & -0.056 & 0.000 & -0.068 & -0.057 & 0.084 \\
\hline & $(0.082)$ & $(0.080)$ & $(0.078)$ & $(0.088)$ & $(0.101)$ \\
\hline \multirow{2}{*}{ Unemployment rate } & -0.011 & -0.059 & 0.036 & 0.012 & 0.026 \\
\hline & $(0.082)$ & $(0.081)$ & $(0.079)$ & $(0.089)$ & $(0.102)$ \\
\hline \multirow{2}{*}{ Employee on non-farm payrolls } & $-0.267^{* *}$ & $-0.260^{* *}$ & $-0.232^{* *}$ & $-0.342^{* * *}$ & $-0.265^{* *}$ \\
\hline & $(0.109)$ & $(0.108)$ & $(0.104)$ & $(0.117)$ & $(0.135)$ \\
\hline \multirow{2}{*}{$\mathrm{CPI}$} & -0.032 & -0.100 & $-0.148^{*}$ & -0.096 & -0.138 \\
\hline & $(0.082)$ & $(0.081)$ & $(0.078)$ & $(0.088)$ & $(0.101)$ \\
\hline \multirow{2}{*}{ PPI } & -0.012 & -0.027 & -0.051 & -0.102 & -0.068 \\
\hline & $(0.091)$ & $(0.089)$ & $(0.087)$ & $(0.098)$ & $(0.112)$ \\
\hline \multirow{2}{*}{ Retail sales } & $0.282^{* * *}$ & 0.139 & $0.242^{* * *}$ & $0.271^{* * *}$ & $0.292^{* * *}$ \\
\hline & $(0.089)$ & $(0.088)$ & $(0.085)$ & $(0.096)$ & $(0.110)$ \\
\hline \multirow{2}{*}{ Personal consumption } & $0.209^{* *}$ & 0.116 & $0.168^{*}$ & 0.170 & 0.138 \\
\hline & $(0.106)$ & $(0.104)$ & $(0.101)$ & $(0.113)$ & $(0.131)$ \\
\hline \multicolumn{6}{|l|}{ Weekly announcements } \\
\hline \multirow{2}{*}{ Initial jobless claims } & $-0.098^{* *}$ & $-0.092 * *$ & $-0.094^{* *}$ & $-0.109 * *$ & -0.081 \\
\hline & $(0.046)$ & $(0.045)$ & $(0.044)$ & $(0.049)$ & $(0.056)$ \\
\hline R-squared & 0.011 & 0.008 & 0.010 & 0.011 & 0.010 \\
\hline Chi-squared & $53.27^{* *}$ & 40.03 & $50.47^{* *}$ & $52.72^{* *}$ & $48.66^{* *}$ \\
\hline \multirow{2}{*}{ Announcements } & \multicolumn{5}{|c|}{ Large OP } \\
\hline & $1 s t(I)$ & $2 n d(I)$ & $3 \mathbf{r d}(\mathrm{I})$ & 4th(I) & $5 \operatorname{th}(\mathrm{I})$ \\
\hline \multicolumn{6}{|l|}{ Quarterly announcements } \\
\hline \multirow[t]{2}{*}{ Real GDP } & 0.232 & 0.0620 & 0.179 & 0.203 & 0.194 \\
\hline & $(0.168)$ & $(0.151)$ & $(0.162)$ & $(0.182)$ & $(0.203)$ \\
\hline Monthly announcements & & & & & \\
\hline ISM non-manufacturino & $0.295^{* *}$ & 0.155 & $0.220^{* *}$ & $0.239^{*}$ & $0.252 *$ \\
\hline & $(0.116)$ & $(0.104)$ & $(0.112)$ & $(0.126)$ & $(0.140)$ \\
\hline Inductrial nroduction & -0.093 & -0.079 & 0.014 & -0.086 & -0.076 \\
\hline Industrial production & $(0.082)$ & $(0.074)$ & $(0.079)$ & $(0.089)$ & $(0.099)$ \\
\hline & 0.074 & 0.085 & -0.016 & 0.125 & 0.055 \\
\hline Leading indicator index & $(0.082)$ & $(0.073)$ & $(0.079)$ & $(0.089)$ & $(0.099)$ \\
\hline & $0.152^{*}$ & 0.100 & $0.168^{* *}$ & 0.104 & 0.140 \\
\hline Trade balance & $(0.082)$ & $(0.074)$ & $(0.079)$ & $(0.089)$ & $(0.099)$ \\
\hline & 0.099 & 0.025 & 0.089 & 0.051 & -0.058 \\
\hline Housing starts & $(0.083)$ & $(0.074)$ & $(0.080)$ & $(0.090)$ & $(0.100)$ \\
\hline & 0.101 & 0.069 & $0.178^{*}$ & 0.084 & 0.141 \\
\hline Construction spending & $(0.097)$ & $(0.087)$ & $(0.094)$ & $(0.105)$ & $(0.117)$ \\
\hline Consumer confidence & -0.100 & $-0.126^{*}$ & -0.047 & -0.055 & 0.054 \\
\hline Consumer confidence & $(0.082)$ & $(0.073)$ & $(0.079)$ & $(0.088)$ & $(0.099)$ \\
\hline & -0.054 & -0.036 & -0.018 & -0.022 & -0.019 \\
\hline Unemployment rate & $(0.083)$ & $(0.074)$ & $(0.080)$ & $(0.089)$ & $(0.100)$ \\
\hline
\end{tabular}


Table 3 (cont). The reaction of portfolios to macroeconomic announcement (SUR)

\begin{tabular}{|c|c|c|c|c|c|}
\hline \multirow{2}{*}{ Announcements } & \multicolumn{5}{|c|}{ Large OP } \\
\hline & $1 \mathrm{st}(\mathrm{I})$ & $2 n d(I)$ & $\operatorname{3rd}(I)$ & 4th(I) & 5 th(I) \\
\hline \multirow{2}{*}{ Employee on non-farm payrolls } & $-0.328^{* * *}$ & $-0.204^{* *}$ & $-0.272 * * *$ & $-0.319^{* * *}$ & $-0.410^{* * *}$ \\
\hline & $(0.109)$ & $(0.098)$ & $(0.105)$ & $(0.118)$ & $(0.132)$ \\
\hline \multirow{2}{*}{$\mathrm{CPI}$} & -0.077 & -0.097 & -0.078 & -0.104 & -0.089 \\
\hline & $(0.082)$ & $(0.074)$ & $(0.079)$ & $(0.089)$ & $(0.099)$ \\
\hline \multirow{2}{*}{ PPI } & -0.035 & -0.075 & -0.032 & -0.139 & -0.033 \\
\hline & $(0.091)$ & $(0.082)$ & $(0.088)$ & $(0.098)$ & $(0.110)$ \\
\hline \multirow{2}{*}{ Retail sales } & $0.184^{* *}$ & $0.191 * *$ & $0.258^{* * *}$ & $0.216^{* *}$ & $0.253^{* *}$ \\
\hline & $(0.089)$ & $(0.080)$ & $(0.086)$ & $(0.097)$ & $(0.108)$ \\
\hline \multirow{2}{*}{ Personal consumption } & 0.126 & 0.101 & 0.114 & 0.115 & 0.073 \\
\hline & $(0.106)$ & $(0.095)$ & $(0.102)$ & $(0.114)$ & $(0.128)$ \\
\hline \multicolumn{6}{|l|}{ Weekly announcements } \\
\hline \multirow{2}{*}{ Initial jobless claims } & $-0.116^{* *}$ & $-0.076^{*}$ & -0.071 & $-0.096^{*}$ & $-0.109^{* *}$ \\
\hline & $(0.046)$ & $(0.041)$ & $(0.044)$ & $(0.049)$ & $(0.055)$ \\
\hline R-squared & 0.013 & 0.009 & 0.010 & 0.010 & 0.010 \\
\hline Chi-squared & $60.81^{* * *}$ & $43.00^{*}$ & $46.97^{* *}$ & $48.72^{* *}$ & $49.19^{* *}$ \\
\hline
\end{tabular}

Notes: 1 . The table displays the coefficients for all macroeconomic announcements using the SUR estimation. The standard error is presented in parentheses. $\left(^{*}\right)$ denotes significance at the $10 \%$ level; $\left({ }^{* *}\right)$ denotes significance at the $5 \%$ level; $\left({ }^{* *}\right)$ denotes significance at the $1 \%$ level. 2 . ith OP denotes the ith portfolio formed on operating profitability ith(I) denotes the ith portfolio formed on investment.

Table 4. The reaction of portfolios to macroeconomic announcements (MM weighted least squares)

\begin{tabular}{|c|c|c|c|c|c|}
\hline \multirow{2}{*}{ Announcements } & \multicolumn{5}{|c|}{ Small OP } \\
\hline & 1st(I) & 2nd(I) & $3 r d(I)$ & 4th(I) & 5th(I) \\
\hline \multicolumn{6}{|c|}{ Quarterly announcements } \\
\hline \multirow{2}{*}{ Real GDP } & 0.020 & 0.126 & 0.099 & 0.123 & 0.161 \\
\hline & $(0.143)$ & $(0.137)$ & $(0.127)$ & $(0.152)$ & $(0.158)$ \\
\hline \multicolumn{6}{|l|}{ Monthly announcements } \\
\hline \multirow{2}{*}{ ISM non-manufacturing } & $0.446^{* *}$ & $0.446^{* * *}$ & $0.458^{* * *}$ & $0.448^{* * *}$ & $0.482 * * *$ \\
\hline & $(0.193)$ & $(0.136)$ & $(0.170)$ & $(0.099)$ & $(0.164)$ \\
\hline \multirow{2}{*}{ Industrial production } & 0.038 & 0.005 & -0.113 & -0.021 & -0.062 \\
\hline & $(0.106)$ & $(0.102)$ & $(0.086)$ & $(0.089)$ & $(0.126)$ \\
\hline \multirow{2}{*}{ Leading indicator index } & -0.068 & 0.069 & 0.053 & -0.013 & -0.043 \\
\hline & (0.089) & $(0.080)$ & $(0.087)$ & $(0.075)$ & $(0.082)$ \\
\hline \multirow{2}{*}{ Trade balance } & 0.047 & 0.000 & 0.046 & 0.117 & 0.113 \\
\hline & $(0.092)$ & $(0.101)$ & $(0.078)$ & $(0.127)$ & $(0.115)$ \\
\hline \multirow{2}{*}{ Housing starts } & -0.045 & -0.017 & $-0.103 *$ & -0.045 & -0.025 \\
\hline & $(0.098)$ & $(0.062)$ & $(0.062)$ & $(0.086)$ & $(0.090)$ \\
\hline \multirow{2}{*}{ Construction spending } & 0.137 & 0.122 & 0.056 & 0.200 & 0.101 \\
\hline & $(0.178)$ & $(0.258)$ & $(0.134)$ & $(0.179)$ & $(0.158)$ \\
\hline \multirow{2}{*}{ Consumer confidence } & 0.053 & 0.028 & 0.040 & 0.009 & 0.029 \\
\hline & $(0.084)$ & $(0.070)$ & $(0.069)$ & $(0.078$ & $(0.088)$ \\
\hline \multirow{2}{*}{ Unemployment rate } & -0.048 & 0.111 & $0.209 * * *$ & 0.040 & 0.022 \\
\hline & $(0.105)$ & $(0.078)$ & $(0.075)$ & $(0.099)$ & $(0.106)$ \\
\hline \multirow{2}{*}{ Employee on non-farm payrolls } & $-0.217^{* *}$ & $-0.140^{*}$ & $-0.242 * * *$ & -0.161 & $-0.239 * *$ \\
\hline & $(0.095)$ & $(0.080)$ & $(0.089)$ & $(0.147)$ & $(0.121)$ \\
\hline \multirow{2}{*}{$\mathrm{CPI}$} & 0.051 & 0.040 & 0.002 & 0.040 & 0.198 \\
\hline & $(0.114)$ & $(0.100)$ & $(0.083)$ & $(0.103)$ & $(0.123)$ \\
\hline \multirow{2}{*}{ PPI } & -0.105 & -0.057 & -0.031 & -0.009 & -0.017 \\
\hline & $(0.087)$ & $(0.070)$ & $(0.106)$ & $(0.119)$ & $(0.102)$ \\
\hline
\end{tabular}


Table 4 (cont.). The reaction of portfolios to macroeconomic announcements (MM weighted least squares)

\begin{tabular}{|c|c|c|c|c|c|}
\hline \multirow{2}{*}{ Announcements } & \multicolumn{5}{|c|}{ Small OP } \\
\hline & $1 s t(I)$ & 2nd(I) & $3 r d(I)$ & 4th(I) & 5 th $(\mathrm{I})$ \\
\hline \multirow{2}{*}{ Retail sales } & 0.006 & 0.104 & $0.135^{* *}$ & $0.171^{* *}$ & 0.138 \\
\hline & $(0.054)$ & $(0.072)$ & $(0.057)$ & $(0.083)$ & $(0.098)$ \\
\hline \multirow{2}{*}{ Consumption expenditure } & 0.003 & 0.017 & 0.041 & 0.063 & 0.084 \\
\hline & $(0.089)$ & $(0.077)$ & $(0.079)$ & $(0.120)$ & $(0.120)$ \\
\hline \multicolumn{6}{|l|}{ Weekly announcements } \\
\hline \multirow{2}{*}{ Initial jobless claims } & $-0.188^{* * *}$ & $-0.090^{*}$ & $-0.130^{* *}$ & $-0.113^{* *}$ & $-0.186^{* * *}$ \\
\hline & $(0.068)$ & $(0.052)$ & $(0.051)$ & $(0.050)$ & $(0.043)$ \\
\hline \multirow{2}{*}{ Announcements } & \multicolumn{5}{|c|}{ 2nd OP } \\
\hline & $1 \mathrm{st}(\mathrm{I})$ & 2nd(I) & $3 r d(I)$ & 4th(I) & 5 th(I) \\
\hline \multicolumn{6}{|l|}{ Quarterly announcements } \\
\hline \multirow[t]{2}{*}{ Real GDP } & 0.186 & 0.134 & $0.156^{*}$ & 0.046 & 0.200 \\
\hline & $(0.123)$ & $(0.145)$ & $(0.083)$ & $(0.172)$ & $(0.147)$ \\
\hline \multicolumn{6}{|l|}{ Monthly announcements } \\
\hline \multirow{2}{*}{ ISM non-manufacturing } & $0.348^{* *}$ & $0.303^{*}$ & $0.297^{*}$ & $0.309^{* *}$ & $0.289^{* * *}$ \\
\hline & $(0.136)$ & $(0.168)$ & $(0.157)$ & $(0.127)$ & $(0.087)$ \\
\hline \multirow{2}{*}{ Industrial production } & -0.051 & -0.025 & 0.047 & -0.019 & -0.065 \\
\hline & $(0.122)$ & $(0.104)$ & $(0.058)$ & $(0.096)$ & $(0.098)$ \\
\hline \multirow{2}{*}{ Leading indicator index } & -0.006 & 0.044 & 0.106 & 0.035 & $0.124^{*}$ \\
\hline & $(0.074)$ & $(0.080)$ & $(0.072)$ & $(0.083)$ & $(0.073)$ \\
\hline \multirow{2}{*}{ Trade balance } & 0.039 & -0.008 & 0.060 & 0.056 & 0.078 \\
\hline & $(0.073)$ & $(0.070)$ & $(0.089)$ & $(0.077)$ & $(0.107)$ \\
\hline \multirow{2}{*}{ Housing starts } & -0.016 & -0.011 & -0.023 & -0.062 & 0.055 \\
\hline & $(0.083)$ & $(0.087)$ & $(0.069)$ & $(0.084)$ & $(0.094)$ \\
\hline \multirow{2}{*}{ Construction spending } & 0.164 & 0.156 & $0.259 * *$ & 0.172 & 0.188 \\
\hline & $(0.132)$ & $(0.134)$ & $(0.112)$ & $(0.150)$ & $(0.129)$ \\
\hline \multirow{2}{*}{ Consumer confidence } & $0.113^{*}$ & 0.129 & 0.089 & 0.044 & 0.047 \\
\hline & $(0.061)$ & $(0.081)$ & $(0.064)$ & $(0.070)$ & $(0.073)$ \\
\hline \multirow{2}{*}{ Unemployment rate } & 0.101 & $0.148^{* *}$ & $0.121^{*}$ & 0.100 & 0.036 \\
\hline & $(0.078$ & $(0.066)$ & $(0.064)$ & $(0.083)$ & $(0.066)$ \\
\hline Emplovee on non-farm pavrolls & $-0.189 * *$ & -0.175 & -0.031 & $-0.184^{*}$ & $-0.306^{* * *}$ \\
\hline Employee on non-farm payrolls & $(0.085)$ & $(0.118)$ & $(0.068)$ & $(0.094)$ & $(0.073)$ \\
\hline CPI & -0.009 & -0.037 & 0.066 & -0.041 & 0.067 \\
\hline CPI & $(0.090)$ & $(0.106)$ & $(0.103)$ & $(0.116)$ & $(0.110)$ \\
\hline & -0.035 & 0.090 & 0.098 & 0.041 & -0.113 \\
\hline PPI & $(0.087)$ & $(0.085)$ & $(0.064)$ & $(0.088)$ & $(0.088)$ \\
\hline & 0.077 & $0.269^{* *}$ & 0.062 & $0.116^{*}$ & 0.024 \\
\hline Retall sales & $(0.070)$ & $(0.119)$ & $(0.075)$ & $(0.064)$ & $(0.049)$ \\
\hline Consumption expenditure & 0.044 & 0.084 & -0.068 & 0.029 & 0.014 \\
\hline Consumption expenaiture & $(0.083)$ & $(0.085)$ & $(0.077)$ & $(0.065)$ & $(0.087)$ \\
\hline Weekly announcements & & & & & \\
\hline & $-0.125^{* * *}$ & -0.069 & $-0.186^{* * *}$ & -0.091 & $-0.114^{* *}$ \\
\hline Inıtıal jobless claıms & $(0.044)$ & $(0.064)$ & $(0.044)$ & $(0.057)$ & $(0.047)$ \\
\hline & & & 3rd OP & & \\
\hline Announcements & $1 \mathrm{st}(\mathrm{I})$ & 2nd(I) & $3 r d(I)$ & 4th(I) & 5 th $(I)$ \\
\hline Quarterly announcements & & & & & \\
\hline & 0.066 & $0.195^{*}$ & $0.155^{*}$ & 0.169 & 0.130 \\
\hline Real GDP & $(0.094)$ & $(0.116)$ & $(0.085)$ & $(0.137)$ & $(0.112)$ \\
\hline Monthly announcements & & & & & \\
\hline ISM non-manufacturing & $0.283^{* *}$ & $0.190^{* *}$ & 0.183 & $0.253^{* * *}$ & $0.380^{* * *}$ \\
\hline ISM non-manutacturing & $(0.138)$ & $(0.097)$ & $(0.112)$ & $(0.082)$ & $(0.109)$ \\
\hline & -0.064 & -0.071 & -0.076 & -0.037 & -0.0451 \\
\hline Industrial production & $(0.093)$ & $(0.088)$ & $(0.075)$ & $(0.076)$ & $(0.083)$ \\
\hline
\end{tabular}


Table 4 (cont.). The reaction of portfolios to macroeconomic announcements (MM weighted least squares)

\begin{tabular}{|c|c|c|c|c|c|}
\hline \multirow{2}{*}{ Announcements } & \multicolumn{5}{|c|}{ 3rd OP } \\
\hline & $1 s t(I)$ & 2nd(I) & $3 \mathrm{rd}(\mathrm{I})$ & 4th(I) & 5 th(I) \\
\hline \multirow{2}{*}{ Leading indicator index } & 0.003 & 0.070 & -0.011 & 0.028 & -0.056 \\
\hline & $(0.078)$ & $(0.077)$ & $(0.057)$ & $(0.062)$ & $(0.078)$ \\
\hline \multirow{2}{*}{ Trade balance } & 0.010 & 0.002 & 0.017 & 0.060 & 0.095 \\
\hline & $(0.064)$ & $(0.089)$ & $(0.081)$ & $(0.090)$ & $(0.092)$ \\
\hline \multirow{2}{*}{ Housing starts } & -0.010 & -0.048 & 0.015 & -0.011 & -0.036 \\
\hline & $(0.076)$ & $(0.065)$ & $(0.064)$ & $(0.064)$ & $(0.065)$ \\
\hline \multirow{2}{*}{ Construction spending } & -0.016 & 0.078 & 0.025 & 0.080 & 0.160 \\
\hline & $(0.087)$ & $(0.111)$ & $(0.111)$ & $(0.118)$ & $(0.134)$ \\
\hline \multirow{2}{*}{ Consumer confidence } & 0.126 & 0.019 & 0.032 & 0.056 & 0.044 \\
\hline & $(0.079)$ & $(0.055)$ & $(0.059)$ & $(0.073)$ & $(0.070)$ \\
\hline \multirow{2}{*}{ Unemployment rate } & 0.083 & 0.031 & 0.091 & 0.093 & 0.012 \\
\hline & $(0.069)$ & $(0.075)$ & $(0.076)$ & $(0.073)$ & $(0.078)$ \\
\hline \multirow{2}{*}{ Employee on non-farm payrolls } & -0.068 & $-0.241^{* * *}$ & $-0.140^{*}$ & -0.066 & $-0.242^{*}$ \\
\hline & $(0.190)$ & $(0.092)$ & $(0.072)$ & $(0.080)$ & $(0.126)$ \\
\hline \multirow{2}{*}{$\mathrm{CPI}$} & -0.028 & 0.069 & -0.044 & 0.031 & 0.029 \\
\hline & $(0.109)$ & $(0.086)$ & $(0.062)$ & $(0.088)$ & $(0.107)$ \\
\hline \multirow{2}{*}{ PPI } & $-0.141^{*}$ & -0.050 & 0.019 & -0.014 & 0.061 \\
\hline & $(0.082)$ & $(0.084)$ & $(0.083)$ & $(0.113)$ & $(0.106)$ \\
\hline \multirow{2}{*}{ Retail sales } & 0.174 & $0.114^{* *}$ & $0.174^{* * *}$ & 0.072 & -0.009 \\
\hline & $(0.293)$ & $(0.050)$ & $(0.063)$ & $(0.073)$ & $(0.101)$ \\
\hline \multirow{2}{*}{ Personal consumption } & -0.030 & 0.071 & 0.004 & -0.025 & 0.018 \\
\hline & $(0.067)$ & $(0.078)$ & $(0.076)$ & $(0.059)$ & $(0.081)$ \\
\hline \multicolumn{6}{|l|}{ Weekly announcements } \\
\hline \multirow{2}{*}{ Initial jobless claims } & $-0.133^{* *}$ & $-0.138^{* * *}$ & $-0.129 * * *$ & $-0.151^{* * *}$ & $-0.122^{* *}$ \\
\hline & $(0.062)$ & $(0.050)$ & $(0.048)$ & $(0.043)$ & $(0.053)$ \\
\hline \multirow{2}{*}{ Announcements } & \multicolumn{5}{|c|}{ 4th OP } \\
\hline & $1 s t(I)$ & $2 \mathrm{nd}(\mathrm{I})$ & $3 r d(I)$ & 4th(I) & 5 th(I) \\
\hline \multicolumn{6}{|l|}{ Quarterly announcements } \\
\hline \multirow[t]{2}{*}{ Real GDP } & 0.056 & $0.151^{* *}$ & 0.170 & 0.148 & $0.238^{*}$ \\
\hline & $(0.108)$ & $(0.075)$ & $(0.126)$ & $(0.097)$ & $(0.141)$ \\
\hline \multicolumn{6}{|l|}{ Monthly announcements } \\
\hline & $0.331^{* * *}$ & 0.091 & 0.090 & 0.112 & $0.303^{* *}$ \\
\hline ISM non-manutacturing & $(0.098)$ & $(0.090)$ & $(0.081)$ & $(0.077)$ & $(0.133)$ \\
\hline & -0.054 & -0.114 & 0.006 & -0.006 & $-0.138^{*}$ \\
\hline Industrial production & $(0.106)$ & $(0.123)$ & $(0.067)$ & $(0.080)$ & $(0.080)$ \\
\hline Iending indiratorindov & 0.068 & 0.110 & -0.035 & 0.045 & 0.039 \\
\hline Leadıng ındıcator ındex & $(0.065)$ & $(0.075)$ & $(0.074)$ & $(0.065)$ & $(0.068)$ \\
\hline Trade balance & 0.072 & 0.090 & 0.038 & -0.005 & 0.051 \\
\hline Irade balance & $(0.056)$ & $(0.067)$ & $(0.072)$ & $(0.074)$ & $(0.098)$ \\
\hline Housing starts & 0.049 & -0.016 & 0.006 & 0.107 & 0.014 \\
\hline Housıng starts & $(0.068)$ & $(0.061)$ & $(0.058)$ & $(0.069)$ & $(0.064)$ \\
\hline & 0.040 & 0.136 & 0.130 & -0.001 & 0.036 \\
\hline Construction spending & $(0.108)$ & $(0.121)$ & $(0.112)$ & $(0.117)$ & $(0.120)$ \\
\hline & 0.073 & 0.060 & 0.0457 & 0.035 & 0.062 \\
\hline Consumer confidence & $(0.069)$ & $(0.098)$ & $(0.075)$ & $(0.069)$ & $(0.068)$ \\
\hline Inemplovment rate & 0.034 & -0.029 & 0.009 & $0.114^{*}$ & $0.146^{*}$ \\
\hline Unemployment rate & $(0.071)$ & $(0.068)$ & $(0.065)$ & $(0.063)$ & $(0.080)$ \\
\hline Emplovon & $-0.114^{*}$ & $-0.179 * * *$ & -0.075 & -0.017 & $-0.302^{* * *}$ \\
\hline Employee on non-farm payrolls & $(0.065)$ & $(0.057)$ & $(0.087)$ & $(0.073)$ & $(0.077)$ \\
\hline & -0.029 & 0.003 & 0.097 & 0.094 & 0.067 \\
\hline CPI & $(0.074)$ & $(0.090)$ & $(0.062)$ & $(0.075)$ & $(0.068)$ \\
\hline
\end{tabular}


Table 4 (cont.). The reaction of portfolios to macroeconomic announcements (MM weighted least squares)

\begin{tabular}{|c|c|c|c|c|c|}
\hline \multirow{2}{*}{ Announcements } & \multicolumn{5}{|c|}{ 4th OP } \\
\hline & 1st(I) & 2nd(I) & $3 r d(I)$ & 4th(I) & 5 th $(\mathrm{I})$ \\
\hline \multirow{2}{*}{ PPI } & 0.067 & 0.011 & 0.029 & -0.087 & 0.025 \\
\hline & $(0.073)$ & $(0.066)$ & $(0.054)$ & $(0.070)$ & $(0.074)$ \\
\hline \multirow{2}{*}{ Retail sales } & $0.164^{* *}$ & $0.212 *$ & $0.116^{* * *}$ & $0.140^{* * *}$ & 0.122 \\
\hline & $(0.072)$ & $(0.123)$ & $(0.041)$ & $(0.043)$ & $(0.076)$ \\
\hline \multirow{2}{*}{ Personal consumption } & 0.017 & 0.007 & 0.012 & -0.003 & 0.049 \\
\hline & $(0.075)$ & $(0.065)$ & $(0.068)$ & $(0.062)$ & $(0.088)$ \\
\hline \multicolumn{6}{|l|}{ Weekly announcements } \\
\hline \multirow{2}{*}{ Initial jobless claims } & -0.100 & $-0.103^{*}$ & $-0.103^{* *}$ & $-0.136^{* * *}$ & $-0.097^{*}$ \\
\hline & $(0.069)$ & $(0.060)$ & $(0.043)$ & $(0.050)$ & $(0.055)$ \\
\hline \multirow{2}{*}{ Announcements } & \multicolumn{5}{|c|}{ Large OP } \\
\hline & 1st(I) & 2nd(I) & $3 \mathbf{r d}(\mathrm{I})$ & 4th(I) & 5 th $(I)$ \\
\hline \multicolumn{6}{|c|}{ Quarterly announcements } \\
\hline \multirow{2}{*}{ Real GDP } & 0.050 & 0.149 & $0.179^{* *}$ & 0.152 & 0.195 \\
\hline & $(0.151)$ & $(0.119)$ & $(0.086)$ & $(0.131)$ & $(0.121)$ \\
\hline \multicolumn{6}{|l|}{ Monthly announcements } \\
\hline \multirow{2}{*}{ ISM non-manufacturing } & $0.249^{* *}$ & 0.119 & $0.204^{* * *}$ & 0.073 & $0.171^{* *}$ \\
\hline & $(0.102)$ & $(0.084)$ & $(0.070)$ & $(0.089)$ & $(0.086)$ \\
\hline \multirow{2}{*}{ Industrial production } & -0.044 & -0.026 & 0.015 & -0.061 & -0.090 \\
\hline & $(0.073)$ & $(0.070)$ & $(0.068)$ & $(0.086)$ & $(0.086)$ \\
\hline \multirow{2}{*}{ Leading indicator index } & 0.001 & 0.046 & -0.021 & 0.030 & -0.090 \\
\hline & $(0.082)$ & $(0.067)$ & $(0.059)$ & $(0.070)$ & $(0.074)$ \\
\hline \multirow{2}{*}{ Trade balance } & 0.105 & 0.018 & 0.022 & 0.043 & 0.017 \\
\hline & $(0.065)$ & $(0.082)$ & $(0.071)$ & $(0.084)$ & $(0.075)$ \\
\hline \multirow{2}{*}{ Housing starts } & 0.031 & -0.019 & 0.063 & 0.068 & -0.011 \\
\hline & $(0.068)$ & $(0.056)$ & $(0.057)$ & $(0.066)$ & $(0.074)$ \\
\hline \multirow{2}{*}{ Construction spending } & 0.074 & 0.036 & 0.069 & 0.030 & 0.043 \\
\hline & $(0.096)$ & $(0.106)$ & $(0.102)$ & $(0.103)$ & $(0.135)$ \\
\hline \multirow{2}{*}{ Consumer confidence } & 0.039 & -0.036 & 0.049 & 0.052 & $0.131 *$ \\
\hline & $(0.064)$ & $(0.063)$ & $(0.065)$ & $(0.073)$ & $(0.077)$ \\
\hline \multirow{2}{*}{ Unemployment rate } & -0.051 & 0.001 & 0.050 & 0.069 & -0.030 \\
\hline & $(0.061)$ & $(0.066)$ & $(0.053)$ & $(0.069)$ & $(0.081)$ \\
\hline \multirow{2}{*}{ Employee on non-farm payrolls } & -0.106 & -0.073 & -0.054 & -0.166 & $-0.316^{* *}$ \\
\hline & $(0.071)$ & $(0.059)$ & $(0.125)$ & $(0.165)$ & $(0.157)$ \\
\hline \multirow{2}{*}{$\mathrm{CPI}$} & -0.004 & -0.048 & 0.044 & 0.069 & $0.187 * *$ \\
\hline & $(0.080)$ & $(0.083)$ & $(0.075)$ & $(0.069)$ & $(0.078)$ \\
\hline \multirow{2}{*}{ PPI } & -0.035 & -0.017 & $0.098^{*}$ & 0.037 & 0.050 \\
\hline & $(0.094)$ & $(0.069)$ & $(0.058)$ & $(0.070)$ & $(0.071)$ \\
\hline Retail sales & 0.152 & 0.087 & $0.131 * * *$ & 0.039 & 0.060 \\
\hline & $(0.471)$ & $(0.205)$ & $(0.049)$ & $(0.041)$ & $(0.052)$ \\
\hline Personal consumntion & -0.048 & 0.011 & -0.026 & 0.050 & 0.006 \\
\hline retsonal consumintion & $(0.065)$ & $(0.066)$ & $(0.049)$ & $(0.076)$ & $(0.098)$ \\
\hline & Week & ouncemen & & & \\
\hline Initial jobless claims & $-0.140^{* *}$ & $-0.098^{* * *}$ & $-0.073^{*}$ & $-0.106^{* *}$ & -0.111 \\
\hline & $(0.059)$ & $(0.038)$ & $(0.040)$ & $(0.045)$ & $(0.069)$ \\
\hline
\end{tabular}

Notes: 1. The table displays the coefficients for all macroeconomic announcements using the SUR estimation. The standard error is presented in parentheses. $\left.{ }^{*}\right)$ denotes significance at the $10 \%$ level; $\left({ }^{* *}\right)$ denotes significance at the $5 \%$ level; $\left({ }^{* *}\right)$ denotes significance at the $1 \%$ level. 2 . ith OP denotes the ith portfolio formed on operating profitability ith(I) denotes the ith portfolio formed on investment. 